\title{
Impact of the COVID-19 Event on Air Quality in Central China
}

\author{
Kaijie Xu' ${ }^{1}$ Kangping Cui ${ }^{* *}$, Li-Hao Young ${ }^{2 *}$, Yen-Kung Hsieh ${ }^{3}$, Ya-Fen Wang ${ }^{4}$, Jiajia Zhang ${ }^{1}$, \\ Shun Wan ${ }^{1}$ \\ ${ }^{1}$ School of Resources and Environmental Engineering, Hefei University of Technology, Hefei 230009, China \\ ${ }^{2}$ Department of Occupational Safety and Health, China Medical University, Taichung 40402, Taiwan \\ ${ }^{3}$ Marine Ecology and Conservation Research Center, National Academy of Marine Research, Kaohsiung 80661, Taiwan \\ ${ }^{4}$ Department of Environmental Engineering, Chung-Yuan Christian University, Taoyuan 32023, Taiwan
}

\begin{abstract}
In early 2020, the COVID-19 epidemic spread globally. This study investigated the air quality of three cities in Hubei Province, Wuhan, Jingmen, and Enshi, central China, from January to March 2017-2020 to analyze the impact of the epidemic prevention and control actions on air quality. The results indicated that in the three cities, during February 2020, when the epidemic prevention and control actions were taken, the average concentrations of atmospheric $\mathrm{PM}_{2.5}, \mathrm{PM}_{10}, \mathrm{SO}_{2}$, $\mathrm{CO}$, and $\mathrm{NO}_{2}$ in the three cities were $46.1 \mu \mathrm{g} \mathrm{m}^{-3}, 50.8 \mu \mathrm{g} \mathrm{m}^{-3}, 2.56 \mathrm{ppb}, 0.60 \mathrm{ppm}$, and $6.70 \mathrm{ppb}$, and were $30.1 \%, 40.5 \%$, $33.4 \%, 27.9 \%$, and $61.4 \%$ lower than the levels in February 2017-2019, respectively. However, the average $\mathrm{O}_{3}$ concentration $(23.1,32.4$, and $40.2 \mathrm{ppb})$ in 2020 did not show a significant decrease, and even increased by $12.7 \%, 14.3 \%$, and $11.6 \%$ in January, February, and March, respectively. This is because a lower concentration of $\mathrm{NO}_{2}$ resulted in constraints on the NO $+\mathrm{O}_{3}$ reaction, and the $\mathrm{O}_{3}$ could not be effectively further depleted. In addition, the average air quality index (AQI) for the three cities in January, February, and March 2020 were 32.2\%, 27.7\%, and 14.9\% lower than the levels in 2017-2019, respectively. Based on the AQIs for the three cities, the combined proportions of Class I and Class II in January, February, and March 2020 increased by 27.9\%, 24.8\%, and 4.3\%, respectively, while the combined proportion of AQI Classes III, IV, $\mathrm{V}$, and VI was reduced from $34.8 \%$ to $15.8 \%$. In addition, in the first three months of 2020, the indicatory air pollutants in the three cities for the AQIs were predominant in the following order: $\mathrm{PM}_{2.5}(72.0 \%), \mathrm{O}_{3}(16.4 \%), \mathrm{PM}_{10}(8.3 \%), \mathrm{NO}_{2}(2.9 \%)$, and $\mathrm{CO}(0.4 \%)$. This study provides useful information for establishing a scientific air pollution control strategy and is a valuable reference for future research on improving urban air quality.
\end{abstract}

Keywords: COVID-19; AQI; $\mathrm{PM}_{2.5} ; \mathrm{PM}_{10} ; \mathrm{SO}_{2} ; \mathrm{CO} ; \mathrm{NO}_{2} ; \mathrm{O}_{3}$.

\section{INTRODUCTION}

At present, the COVID-19 epidemic that broke out at the end of 2019 continues to spread globally, and the situation is still very serious. On April 12, 2020, globally, there were 1,771,514 COVID-19 confirmed cases and 108,503 deaths (http://www.xinhuanet.com/2020-04/12/c 1125845334.htm).

In order to eliminate the spread of the epidemic, the Chinese government immediately took effective prevention and control actions. On January 24, 2020, Hubei Province government, China, announced the launch of a first-level response to major public health emergencies, which included actions such as quarantining, traffic restrictions, and factory closures, which were immediately implemented. The above prevention and

\footnotetext{
${ }^{*}$ Corresponding author.

E-mail address: cuikangping@163.com (K. Cui); lhy@mail.cmu.edu.tw (L.H. Young)
}

control actions were closely related to the air quality at the time.

The Air Quality Index (AQI) typically reflects the degree of air cleanliness or the level of air pollution and focuses on the assessment of a crowd breathing for a specific period of time (acute or chronic) and the effects of air pollution on their health.

Air quality has become a serious concern of both the Chinese government and the public. Many scholars have conducted air quality assessments in China, reflecting the current problems and proposing control strategies for improvements in air pollution (Wang et al., 2014; Hu et al., 2015; Tong et al., 2016; Lee et al., 2018).

In this study, the air quality of three cities (Wuhan, Jingmen and Enshi) in Hubei Province, central China, including the air pollutants $\mathrm{PM}_{2.5}, \mathrm{PM}_{10}, \mathrm{SO}_{2}, \mathrm{NO}_{2}, \mathrm{CO}$, and $\mathrm{O}_{3}$, and $\mathrm{AQIs}$ from January to March 2017-2020 were investigated, compared, and discussed. In addition, the impact of the COVID-19 epidemic prevention and control actions on air quality was specifically addressed. 


\section{METHODS}

From January to March, 2017-2020, the air quality in three cities in Hubei Province including Wuhan $\left(30^{\circ} 35^{\prime} \mathrm{N}\right.$, $\left.114^{\circ} 17^{\prime} \mathrm{E}\right)$, Jingmen $\left(31^{\circ} 02^{\prime} \mathrm{N}, 112^{\circ} 12^{\prime} \mathrm{E}\right)$ and Enshi Tujia and Miao Autonomous Prefecture $\left(30^{\circ} 16^{\prime} \mathrm{N}, 109^{\circ} 29^{\prime} \mathrm{E}\right)$ (abbreviated as Enshi) (Fig. 1), were studied. The air pollutant levels of $\mathrm{PM}_{2.5}, \mathrm{PM}_{10}, \mathrm{SO}_{2}, \mathrm{NO}_{\mathrm{x}}, \mathrm{CO}$, and $\mathrm{O}_{3}$ in these three cities were investigated (http://www.tianqihoubao.com/lishi/).

Wuhan City is located in the eastern part of Hubei Province, in the middle and lower reaches of the Yangtze River Plain, with a subtropical monsoon humid climate. The average temperatures in Wuhan 2017-2020 ranged between -5 and $22^{\circ} \mathrm{C}$, between -5 and $25^{\circ} \mathrm{C}$, and between 7.4 and $15.2^{\circ} \mathrm{C}$, and averaged $4.0,6.6$, and $10.9^{\circ} \mathrm{C}$, in January, February and March, respectively.

Jingmen City is located in the central part of Hubei Province, and its entire territory is dominated by mountains, with a subtropical warm monsoon climate. During 20172020, the average temperatures in Jingmen ranged from $-7^{\circ} \mathrm{C}$ to $15^{\circ} \mathrm{C}$, from $-4^{\circ} \mathrm{C}$ to $22^{\circ} \mathrm{C}$, and from $0^{\circ} \mathrm{C}$ to $25^{\circ} \mathrm{C}$, and averaged $3.8,6.1$, and $10.3^{\circ} \mathrm{C}$, in January, February and March, respectively.

Enshi is located in southwestern Hubei Province and has a subtropical monsoon humid mountain climate. During $2017-$ 2020, the average temperatures in Enshi ranged from -4 to $14^{\circ} \mathrm{C}$, from 0 to $19^{\circ} \mathrm{C}$, and from 4 to $27^{\circ} \mathrm{C}$, and averaged 5.2 , 7.1 , and $10.9^{\circ} \mathrm{C}$, in January, February, and March, respectively.

\section{AIR QUALITY INDEX (AQI)}

The AQI is a dimensionless index that quantitatively describes the status of air quality. As indicated in Eq. (1), the sub-AQIs of the six criteria pollutants $\left(\mathrm{PM}_{2.5}, \mathrm{PM}_{10}, \mathrm{SO}_{2}\right.$, $\mathrm{CO}, \mathrm{NO}_{2}$, and $\mathrm{O}_{3}$ ) were first calculated with the observation concentrations. The AQI comes from the maximum of the sub-AQI of all pollutants, as shown in Eq. (2), where when the AQI is higher than 50 , contributor of the maximum sub-
AQI is defined as the primary pollutant on that day (She et al., 2017; Shen et al., 2017).

$I A Q I_{P}=\frac{I_{\text {high }}-I_{\text {low }}}{C_{\text {high }}-C_{\text {low }}}\left(C_{P}-C_{\text {low }}\right)+I_{\text {low }}$

$A Q I=\max \left(I_{1}, I_{2}, \ldots, I_{n}\right)$

$I A Q I_{P}$ : the air quality sub index for air pollutant $\mathrm{p}$;

$C_{P}$ : the concentration of pollutant $\mathrm{p}$;

$C_{\text {low }}$ : the concentration breakpoint that is $\leq C_{P}$;

$C_{\text {high }}$ : the concentration breakpoint that is $\geq C_{P}$;

$I_{\text {low }}$ : the index breakpoint corresponding to $C_{\text {low }}$;

$I_{\text {high }}$ : the index breakpoint corresponding to $C_{\text {high }}$.

Ambient air quality is closely related to the development of human society and has a major impact on human health. The AQI simplifies the concentrations of different pollutants into a single numerical value to reflect overall air quality. The daily AQI value is calculated from the 24-hour average concentrations of $\mathrm{PM}_{2.5}, \mathrm{PM}_{10}, \mathrm{SO}_{2}, \mathrm{CO}, \mathrm{NO}_{2}$, and the daily maximum 8-hour concentration of $\mathrm{O}_{3}$.

Class I: 0-50 (Green), Good.

Class II: 51-100 (Yellow), Moderate.

Class III: 101-150 (Orange), Unhealthy for Sensitive Groups.

Class IV: 151-200 (Red), Unhealthy.

Class V: 201-300 (Purple), Very unhealthy.

Class VI: 300-500 (Maroon), Hazardous.

\section{RESULTS AND DISCUSSION}

\section{Comparison for Air Pollutants}

The average concentrations for $\mathrm{PM}_{2.5}, \mathrm{PM}_{10}, \mathrm{SO}_{2}, \mathrm{CO}$, $\mathrm{NO}_{2}$, and $\mathrm{O}_{3}$ in January, February and March 2017-2019 and those of 2020, respectively, are shown and compared in Figs. 2(A)-2(F), respectively.

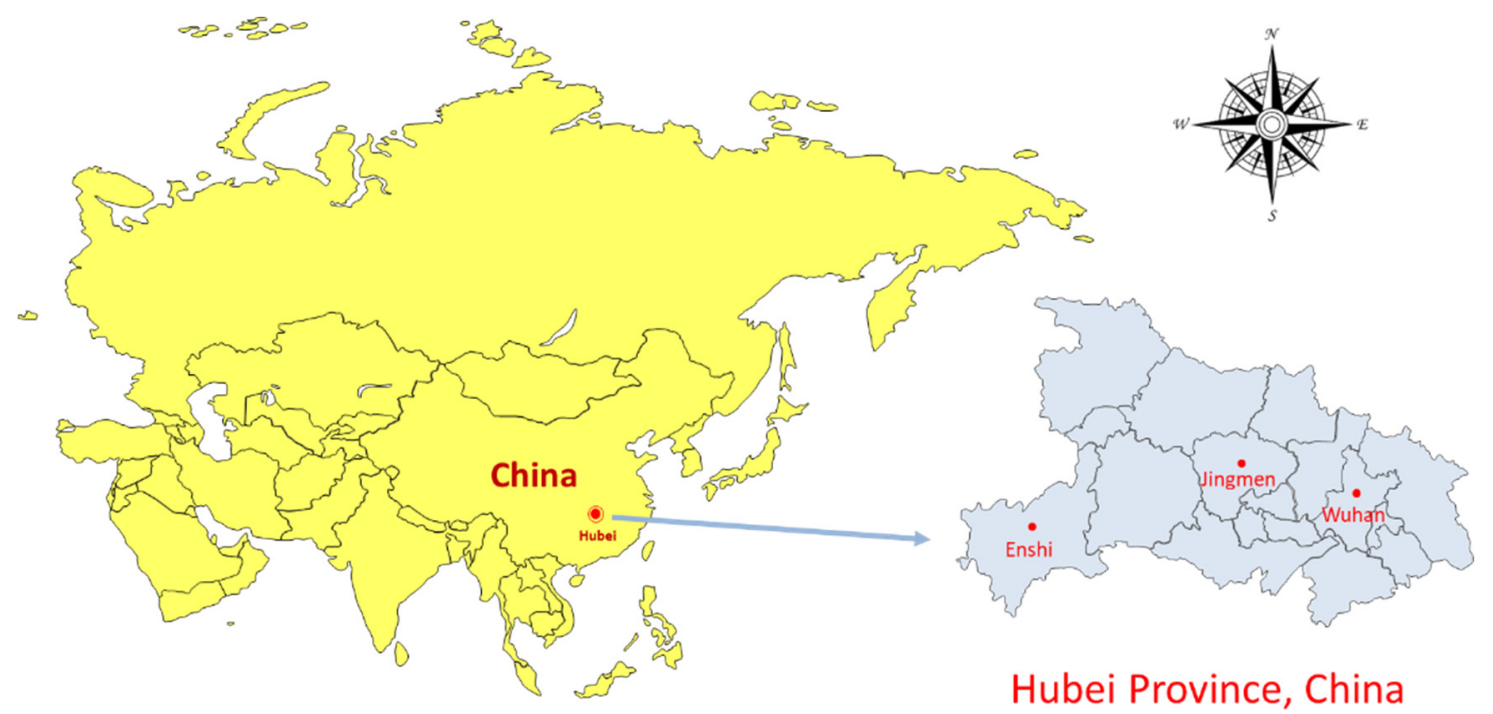

Fig. 1. Location of Wuhan, Jingmen, and Enshi in Hubei Province, China. 
Atmospheric particulate matter is a mixture that includes organic components, inorganic ions, mineral dust, and so on. $\mathrm{PM}_{2.5}$ refers to atmospheric particles with a particle size of less than $2.5 \mu \mathrm{m}$, which are easily accumulated in the human respiratory tract and seriously affect human health. Studies have shown that $\mathrm{PM}_{2.5}$ pollution is closely related to human morbidity or mortality (Dockery et al., 1993; Pope III et al., 2002) and that pollution is more severe in winter (Tao et al., 2009; Xu et al., 2017; Ning et al., 2018; Zhao et al., 2018b).

As shown in Fig. 2(A)(a), during January 2017-2019, in Wuhan, Jingmen, and Enshi, the $\mathrm{PM}_{2.5}$ concentrations ranged between 17 and 198, 20 and 298, and 22 and $248 \mu \mathrm{g} \mathrm{m}^{-3}$ and averaged $88.8,115$, and $77.1 \mu \mathrm{g} \mathrm{m}^{-3}$, respectively. Those during January 2020 were in the range of 12-108, 26-146, and $15-70 \mu \mathrm{g} \mathrm{m} \mathrm{m}^{-3}$, with averages of $59.6,87.8$, and $36.8 \mathrm{\mu g} \mathrm{m}^{-3}$, respectively, and were $32.9 \%, 23.5 \%$, and $52.2 \%$ lower than those during January 2017-2019. Based on the data from the three cities, during January 2020, the average $\mathrm{PM}_{2.5}$ decreased by $36.2 \%$ compared with that in January 2017-2019.

As shown in Fig. 2(A)(b), in Wuhan, Jingmen, and Enshi, during February 2017-2019, the $\mathrm{PM}_{2.5}$ concentrations ranged between 16 and 165, 24 and 179, and 12 and $116 \mu \mathrm{g} \mathrm{m}^{-3}$ and averaged $67.9,82.1$, and $51.5 \mu \mathrm{g} \mathrm{m}^{-3}$, respectively. Those during February 2020 ranged from 9-97, 12-139, and 12$92 \mu \mathrm{g} \mathrm{m}^{-3}$, averaged $38.0,57.1$, and $43.4 \mu \mathrm{g} \mathrm{m}^{-3}$, respectively, and were $44.0 \%, 30.5 \%$, and $15.7 \%$ lower than those during February 2017-2019. Based on the data from the three cities, during February 2020, the average $\mathrm{PM}_{2.5}$ concentration decreased by $30.1 \%$ compared with that in February 2017 2019.

As shown in Fig. 2(A)(c), in Wuhan, Jingmen, and Enshi, during March 2017-2019, the $\mathrm{PM}_{2.5}$ concentrations ranged from $23-223,11-104$, and $10-70 \mu \mathrm{g} \mathrm{m}^{-3}$ and averaged 53.1, 51.6, and $35.1 \mu \mathrm{g} \mathrm{m}^{-3}$, respectively. Those during March 2020 ranged from $8-57,8-83$, and 5-95 $\mu \mathrm{g} \mathrm{m}^{-3}$, and averaged $34.5,44.3$, and $35.7 \mu \mathrm{g} \mathrm{m}^{-3}$, respectively. Levels in Wuhan and Jingmen were $35.1 \%$ and $14.1 \%$ lower, respectively, than those during March 2017-2019, but in Enshi, there was a $1.7 \%$ increase. Based on the data from the three cities, $\mathrm{PM}_{2.5}$ decreased by $15.8 \%$ on average compared with March 2017-2019.

It can be seen that the average concentration of $\mathrm{PM}_{2.5}$ decreased from January to March 2020. There may be two reasons for this significant reduction in January. The first is that the second half of January 2020 is the lunar New Year holiday in China. As a result, most factories were closed, and the employees were on vacation, which resulted in a significant reduction in industrial emissions. Secondly, since January 23, 2020, Hubei Province has implemented strict epidemic prevention and control actions, which led to traffic stagnation and factory closures, thus greatly reducing both emissions from automobile exhaust and industrial production. The reason for the decrease in $\mathrm{PM}_{2.5}$ concentration in February 2020 was due to strict epidemic prevention and control actions. In March, under these actions, $\mathrm{PM}_{2.5}$ concentrations in Wuhan and Jingmen still showed a downward trend, but in Enshi, there was an increase of $1.7 \%$. This may be because a better ecological environment in Enshi leads to lower $\mathrm{PM}_{2.5}$ levels, and at the same time, the temperature rise in March was more conducive to the dispersion of air pollutants. Therefore, the epidemic prevention and control actions did not have a significant impact on the air quality in Enshi.

$\mathrm{PM}_{10}$ refers to atmospheric particulate matter with a diameter of less than 10 microns, mainly derived from industrial exhaust emissions, fossil fuel combustion, motor vehicle exhaust, and dust entrainment (Kong et al., 2011). Airborne particulate pollution is extremely detrimental to human health and affects the human respiratory and nervous systems (Wang and Chen, 2016).

As shown in Fig. 2(B)(a), in Wuhan, Jingmen, and Enshi, during January 2017-2019, the $\mathrm{PM}_{10}$ concentrations ranged between 14 and 201, 15 and 251, and 26 and $292 \mu \mathrm{g} \mathrm{m}^{-3}$ and averaged 99.6, 110.3, and $101.1 \mathrm{~g} \mathrm{~m} \mathrm{~m}^{-3}$, respectively. Those during January 2020 ranged from 19-135, 10-128, and 21$114 \mu \mathrm{g} \mathrm{m}^{-3}$, with averages of $69.9,73.7$, and $50.7 \mu \mathrm{g} \mathrm{m}^{-3}$, respectively, which were $29.8 \%, 33.2 \%$, and $49.8 \%$ lower than those during January 2017-2019. Based on the data from the three cities, during January 2020, the average $\mathrm{PM}_{10}$ decreased by $37.6 \%$ compared with that in January $2017-$ 2019.

As shown in Fig. 2(B)(b), in Wuhan, Jingmen, and Enshi, during February 2017-2019, the $\mathrm{PM}_{10}$ concentrations ranged between 13 and 211, 29 and 218, and 24 and $150 \mu \mathrm{g} \mathrm{m}^{-3}$ and averaged 88.2, 105.0, and $69.6 \mu \mathrm{g} \mathrm{m}^{-3}$, respectively. Those during February 2020 ranged from 12-103, 13-122, and 21$101 \mu \mathrm{g} \mathrm{m}^{-3}$, with averages of $46.0,54.2$, and $52.1 \mu \mathrm{g} \mathrm{m}^{-3}$, respectively, which were $47.9 \%, 48.4 \%$, and $25.1 \%$ lower

\section{$\mathbf{P M}_{2.5}$ concentration}

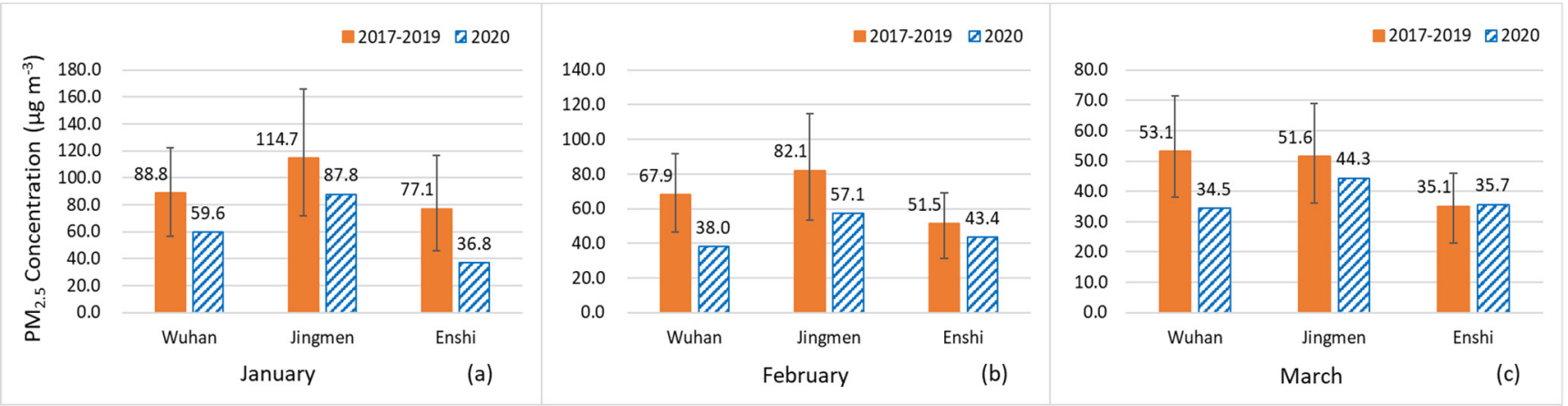

Fig. 2(A). The average $\mathrm{PM}_{2.5}$ concentrations during January, February and March 2017-2019 and those of 2020, respectively. 


\section{PM10 concentration}

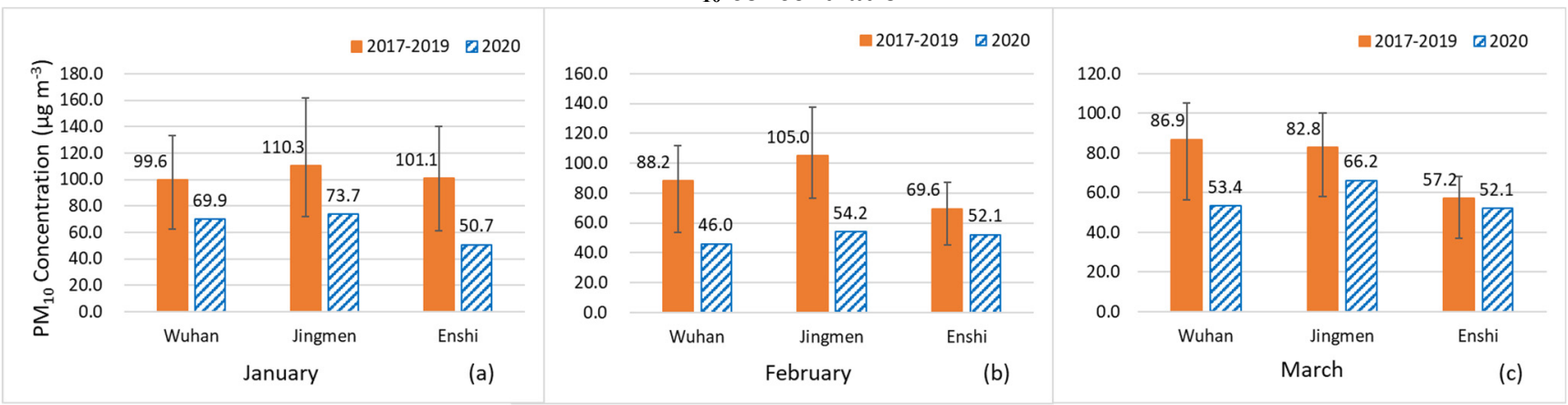

Fig. 2(B). The average concentrations of $\mathrm{PM}_{10}$ in January, February, and March 2017-2019 and those of 2020, respectively.

than those during February 2017-2019. Based on the data from the three cities, during February 2020, the average $\mathrm{PM}_{10}$ decreased by $40.5 \%$ compared with that in February 2017-2019.

As shown in Fig. 2(B)(c), in Wuhan, Jingmen, and Enshi, during March 2017-2019, the $\mathrm{PM}_{10}$ concentrations ranged between 21 and 244, 20 and 175, and 11 and $112 \mu \mathrm{g} \mathrm{m}^{-3}$ and averaged $86.9,82.8$, and $57.2 \mu \mathrm{g} \mathrm{m}^{-3}$, respectively. Those during March 2020 ranged from 13-88, 17-153, and 15$124 \mu \mathrm{g} \mathrm{m}^{-3}$, with averages of $55.4,66.2$, and $52.1 \mu \mathrm{g} \mathrm{m}^{-3}$, respectively, which were $38.6 \%, 20.0 \%$, and $8.9 \%$ lower than that of during March 2017-2019. Based on the data from the three cities, during March 2020, the average $\mathrm{PM}_{10}$ decreased by $22.5 \%$ compared with that in March 2017-2019.

It can be seen that the concentration of $\mathrm{PM}_{10}$ decreased significantly from January to March 2020, especially in February when strict prevention and control actions were taken. A decrease in $\mathrm{PM}_{10}$ in January 2020 can be attributed to the reduction in construction dust and industrial production emissions during the Lunar New Year holidays. The reduction in February and March can be attributed to the strict implementation of epidemic prevention and control actions, which resulted in a substantial reduction in mobile exhaust emissions.

Artificially generated $\mathrm{SO}_{2}$ mainly comes from the combustion of coal, petroleum, and chemical fuels. $\mathrm{SO}_{2}$ in the air is easily oxidized into $\mathrm{SO}_{3}$, which then develops into acid rain, causing damage to surface vegetation and buildings (Kato et al., 2016).

As shown in Fig. 2(C)(a), in Wuhan, Jingmen, and Enshi, during January 2017-2019, the $\mathrm{SO}_{2}$ concentrations ranged between 1.40 and 9.45, 2.10 and 15.1, and 1.40 and $11.9 \mathrm{ppb}$ and averaged $3.84,6.08$, and $2.95 \mathrm{ppb}$, respectively. Those during January 2020 ranged from $1.75-3.85,2.10-5.95$, and $1.40-2.80 \mathrm{ppb}$, with averages of $2.30,3.42$, and $1.45 \mathrm{ppb}$, respectively, which were $40.1 \%, 43.8 \%$, and $51.1 \%$ lower than those during January 2017-2019. Based on the data from the three cities, during January 2020, the average $\mathrm{SO}_{2}$ decreased by $45.0 \%$ compared with that in January 2017 2019.

As shown in Fig. 2(C)(b), in Wuhan, Jingmen, and Enshi, during February 2017-2019, the $\mathrm{SO}_{2}$ concentrations ranged between 1.05 and 9.80, 1.75 and 12.6, and 1.05 and $7.35 \mathrm{ppb}$ and averaged $3.79,5.47$, and $2.28 \mathrm{ppb}$, respectively. Those during February 2020 ranged from 1.75-4.55, 2.45-5.60, and $1.40-1.75 \mathrm{ppb}$, with averages of $2.66,3.56$, and $1.47 \mathrm{ppb}$, respectively, which were $29.9 \%, 34.9 \%$, and $35.4 \%$ lower than those during February 2017-2019. Based on the data from the three cities, during February 2020, the average $\mathrm{SO}_{2}$ decreased by $33.4 \%$ compared with that in February $2017-$ 2019.

As shown in Fig. 2(C)(c), in Wuhan, Jingmen, and Enshi, during March 2017-2019, the $\mathrm{SO}_{2}$ concentrations ranged between 1.05 and 10.2, 2.10 and 17.2, and 1.05 and $7.10 \mathrm{ppb}$ and averaged 3.56, 5.67, and $2.85 \mathrm{ppb}$, respectively. Those during March 2020 ranged from 1.75-5.95, 2.10-7.0, and $1.40-2.10 \mathrm{ppb}$, with averages of $3.14,3.62$, and $1.67 \mathrm{ppb}$, respectively, which were $11.8 \%, 36.1 \%$, and $41.3 \%$ lower than those during March 2017-2019. Based on the data from the three cities, during March 2020, the average $\mathrm{SO}_{2}$ decreased by $29.7 \%$ compared with that in March 2017-2019.

It can be seen that the $\mathrm{SO}_{2}$ concentration of the three cities significantly decreased from January to March in 2020, which shows that the suspension of production caused by the Chinese New Year holiday and factory closures due to epidemic prevention and control actions resulted in a significant reduction in $\mathrm{SO}_{2}$ emissions.

Carbon monoxide (CO) is one of the important indicators of air pollutants that are mainly derived from incomplete combustion activities such as fuel combustion and automobile exhaust emissions related to human activities. High concentrations of $\mathrm{CO}$ pose a major threat to human health and can quickly cause hypoxia in humans, leading to dizziness and even death (Scharte et al., 2000; Li et al., 2017).

As shown in Fig. 2(D)(a), in Wuhan, Jingmen, and Enshi, during January 2017-2019, the CO concentrations ranged between 0.48 and 1.76, 0.56 and 1.92, and 0.48 and 1.92 ppm, and averaged 1.03, 1.04, and 0.99 ppm, respectively. Those during January 2020 ranged from $0.40-1.28$, 0.481.12 , and $0.32-0.96 \mathrm{ppm}$, with averages of $0.79,0.78$, and $0.62 \mathrm{ppm}$, respectively, which were $23.8 \%, 25.0 \%$, and $37.6 \%$ lower than those of during January 2017-2019. Based on the data from the three cities, during January 2020, the average CO decreased by $28.8 \%$ compared with that in January 2017-2019.

As shown in Fig. 2(D)(b), in Wuhan, Jingmen, and Enshi, during February 2017-2019, the CO concentrations ranged between 0.32 and 1.36, 0.56 and 1.12, and 0.32 and $1.12 \mathrm{ppm}$, 
$\mathrm{SO}_{2}$ concentration

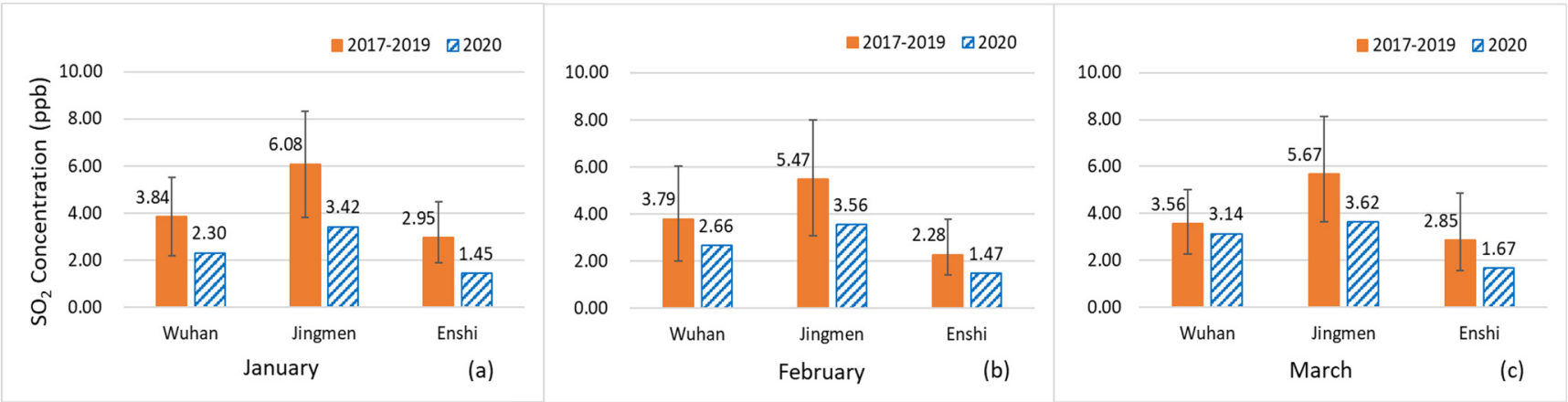

Fig. 2(C). The average concentrations of $\mathrm{SO}_{2}$ in January, February, and March 2017-2019 and those of 2020, respectively.

\section{CO concentration}

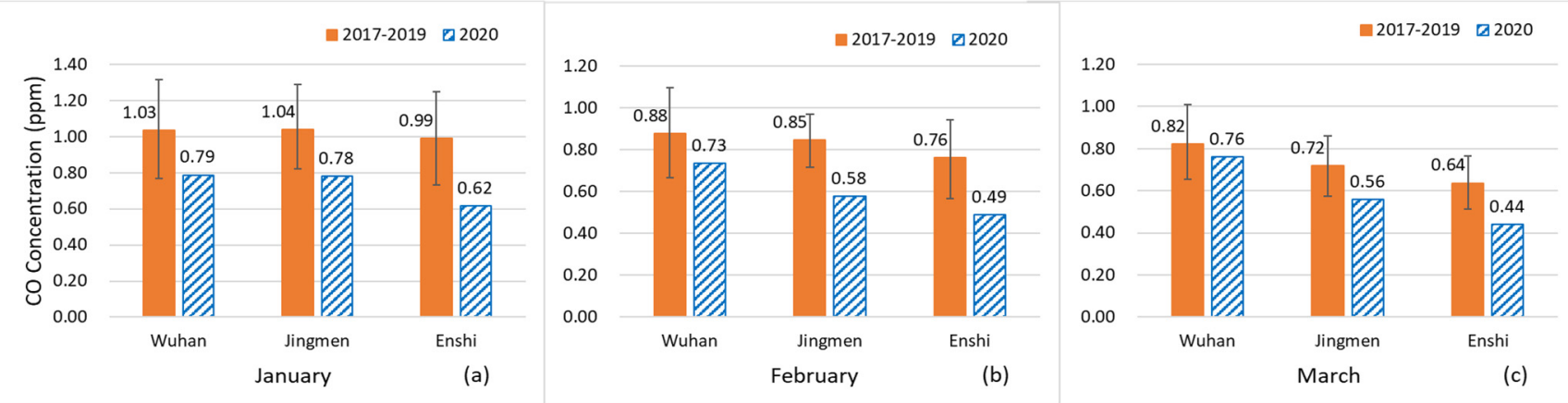

Fig. 2(D). The average concentrations of CO in January, February, and March 2017-2019 and those of 2020, respectively.

and averaged $0.88,0.85$, and $0.76 \mathrm{ppm}$, respectively. Those during February 2020 ranged from $0.48-1.04$, 0.32-0.80, and $0.24-0.64 \mathrm{ppm}$ and averaged $0.73,0.58$, and $0.49 \mathrm{ppm}$, respectively, which were $16.2 \%, 31.9 \%$, and $35.8 \%$ lower than those during February 2017-2019. Based on the data from the three cities, during February 2020, the average CO decreased by $27.9 \%$ compared with that in February 2017-2019.

As shown in Fig. 2(D)(c), in Wuhan, Jingmen, and Enshi, during March 2017-2019, the CO concentrations ranged between 0.48 and $1.60,0.40$ and 1.12 , and 0.32 and $1.12 \mathrm{ppm}$, and averaged $0.82,0.72$, and $0.64 \mathrm{ppm}$, respectively. Those during March 2020 ranged from 0.48-1.12, 0.24-0.96, and $0.24-0.72 \mathrm{ppm}$ and averaged $0.76,0.56$, and $0.44 \mathrm{ppm}$, respectively, which were $7.4 \%, 22.4 \%$, and $31.1 \%$ lower than those during March 2017-2019. Based on the data from the three cities, during March 2020, the average CO decreased by $20.3 \%$ compared with that in March 2017-2019.

In the first three months of 2020 , the CO concentration also showed a significant decrease compared with the same period in the previous three years. This shows that the Lunar New Year holiday and the implementation of epidemic prevention and control actions greatly reduced both the burning of industrial fossil fuels and the traffic flow, thus reducing $\mathrm{CO}$ emissions.

Nitrogen dioxide $\left(\mathrm{NO}_{2}\right)$ is an important pollutant and oxidant in the atmosphere, mainly derived from hightemperature combustion of fossil fuels, thermal power generation, industrial emissions, and automobile exhaust (Burnett et al., 2004; Jaeglé et al., 2005). Ambient $\mathrm{NO}_{2}$ is associated with a variety of health hazards. High concentrations of $\mathrm{NO}_{2}$ can lead to the formation of acid rain and nitrate aerosols, and are also important precursors for $\mathrm{O}_{3}$ production (Biswas et al., 2019).

As shown in Fig. 2(E)(a), in Wuhan, Jingmen, and Enshi, during January 2017-2019, the $\mathrm{NO}_{2}$ concentrations ranged between 8.28 and 48.7, 6.82 and 54.1, and 6.33 and $35.1 \mathrm{ppb}$, and averaged $25.7,22.9$, and $15.2 \mathrm{ppb}$, respectively. Those during January 2020 ranged from 4.87-37.0, 4.87-30.2, and 2.92-17.0 ppb and averaged 17.9, 14.1, and $9.39 \mathrm{ppb}$, respectively, which were $30.3 \%, 38.5 \%$, and $38.1 \%$ lower than those during January 2017-2019. Based on the data from the three cities, during January 2020, the average $\mathrm{NO}_{2}$ decreased by $35.6 \%$ compared with that in January 2017-2019.

As shown in Fig. 2(E)(b), in Wuhan, Jingmen, and Enshi, during February 2017-2019, the $\mathrm{NO}_{2}$ concentrations ranged between 6.33 and 50.2, 6.34 and 35.1, and 4.87 and $21.4 \mathrm{ppb}$, and averaged $30.0,16.8$, and $10.6 \mathrm{ppb}$, respectively. Those during the epidemic prevention and control action period (February 2020) ranged from 4.87-17.5, 2.92-12.7, and $1.46-6.82 \mathrm{ppb}$, with averages of $10.41,6.01$, and 3.68 $\mathrm{ppb}$, respectively, which were $54.7 \%, 64.3 \%$, and $65.2 \%$ lower than that of during February 2017-2019. Based on the data from the three cities, during February 2020, average $\mathrm{NO}_{2}$ decreased by $61.4 \%$ compared with that in February 2017-2019.

As shown in Fig. 2(E)(c), in Wuhan, Jingmen, and Enshi, during March 2017-2019, the $\mathrm{NO}_{2}$ concentrations ranged between 11.2 and 43.3, 6.33 and 35.1, and 4.87 and $21.4 \mathrm{ppb}$ 
and averaged 26.6, 17.8, and $13.1 \mathrm{ppb}$, respectively. Those during March ranged from 6.82-15.6, 3.90-11.7, and 2.92$13.6 \mathrm{ppb}$, with averages of $10.5,6.60$, and $7.05 \mathrm{ppb}$, respectively, which were $60.6 \%, 63.0 \%$, and $46.2 \%$ lower than those during March 2017-2019. Based on the data from the three cities, during March 2020, average $\mathrm{NO}_{2}$ decreased by $56.6 \%$ compared with that in March 2017-2019.

From January to March 2020, the decrease in $\mathrm{NO}_{2}$ concentration is of great significance, and the reduction rate is much higher than other pollutants. Especially in February and March when the epidemic prevention and control actions were taken, the $\mathrm{NO}_{2}$ concentration decreased by more than $60 \%$ compared with the same period in 2019-2019. This may have been because during the epidemic prevention and control actions, industrial production activities and transportation were greatly restricted, resulting in a sharp reduction in the emission of $\mathrm{NO}_{2}$ from both industrial production and vehicle exhaust.

Ozone $\left(\mathrm{O}_{3}\right)$ is an important gas in the process of atmospheric chemical reactions and is also one of the key greenhouse gases. Due to the rapid development that has occurred in the past few decades, power plant emissions, industrial exhaust gas, and the burning of fossil fuels have indirectly caused increased ambient $\mathrm{O}_{3}$ pollution (Logan et al., 1981; Ryerson et al., 2001). Solar radiation and higher air humidity, as well as increased $\mathrm{NO}_{\mathrm{x}}$ and VOCs (volatile organic compounds) in the environment, promote the photochemical reaction that produces $\mathrm{O}_{3}$.

It is worth noting that the pattern of $\mathrm{O}_{3}$ concentration was completely opposite to the pattern of the other five air pollutants. As shown in Fig. 2(F)(a), in Wuhan, Jingmen, and Enshi, during January 2017-2019, the $\mathrm{O}_{3}$ concentrations ranged between 2.80 and $42.0,6.53$ and 49.9 , and 1.87 and $34.5 \mathrm{ppb}$ and averaged 20.4, 26.8, and $14.2 \mathrm{ppb}$, respectively. Those during January 2020 ranged from 2.33-51.3, 9.8061.1, and 2.80-30.8 ppb and averaged $22.3,31.0$, and $16.1 \mathrm{ppb}$, respectively, which was an increase of $9.6 \%, 15.5 \%$, and $13.1 \%$ compared with that of during January 2017-2019. Based on the data from the three cities, during January 2020, the average $\mathrm{O}_{3}$ rose by $12.7 \%$ compared with that in January 2017-2019.

As shown in Fig. 2(F)(b), in Wuhan, Jingmen, and Enshi, during February 2017-2019, the $\mathrm{O}_{3}$ concentrations ranged between 9.33 and 57.9, 11.7 and 62.5, and 1.87 and $47.6 \mathrm{ppb}$ and averaged $27.7,36.3$, and $21.0 \mathrm{ppb}$, respectively. Those during February 2020 ranged from 18.2-49.5, 19.1-54.1, and 8.40-33.6 ppb, and averaged 35.2, 39.5, and $22.4 \mathrm{ppb}$, respectively, which was an increase of $27.1 \%, 8.9 \%$, and $6.9 \%$ compared with that of during February 2017-2019. Based on the data from the three cities, during February 2020 , the average $\mathrm{O}_{3}$ rose by $14.3 \%$ compared with that in February 2017-2019.

As shown in Fig. 2(F)(c), in Wuhan, Jingmen, and Enshi, during March 2017-2019, the $\mathrm{O}_{3}$ concentrations ranged between 5.13 and $65.8,19.1$ and 72.3 , and 2.33 and $48.1 \mathrm{ppb}$ and averaged $36.2,44.6$, and $28.2 \mathrm{ppb}$, respectively. Those during March 2020 ranged from 24.7-63.5, 22.4-72.3, and 14.0-51.3 ppb, and averaged 42.1, 44.6, and $28.2 \mathrm{ppb}$, respectively, which was an increase of $16.3 \%, 3.2 \%$, and

\section{$\mathrm{NO}_{2}$ concentration}
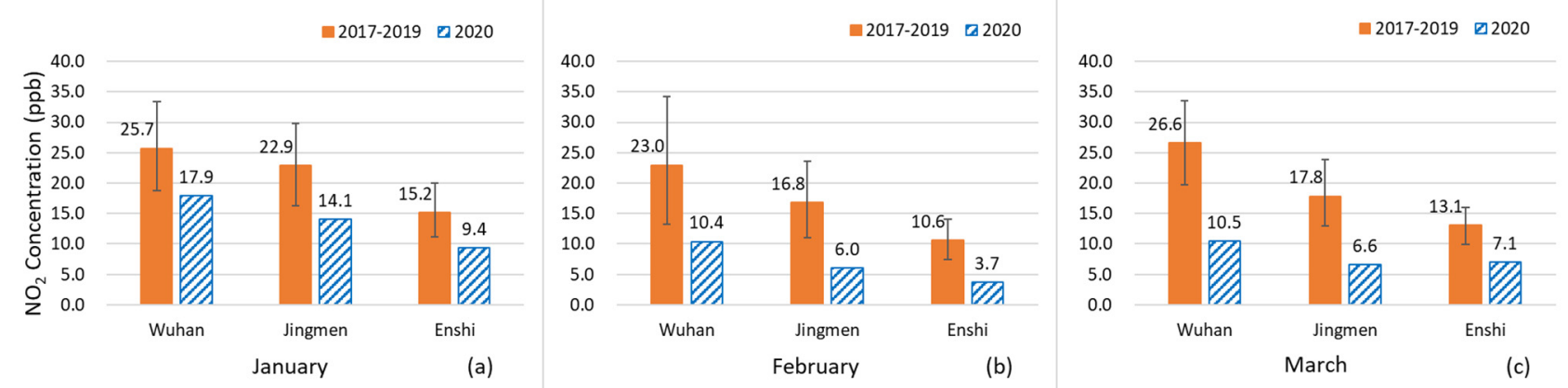

Fig. 2(E). The average concentrations of $\mathrm{NO}_{2}$ in January, February, and March 2017-2019 and those of 2020, respectively.

\section{$\mathrm{O}_{3}$ concentration}
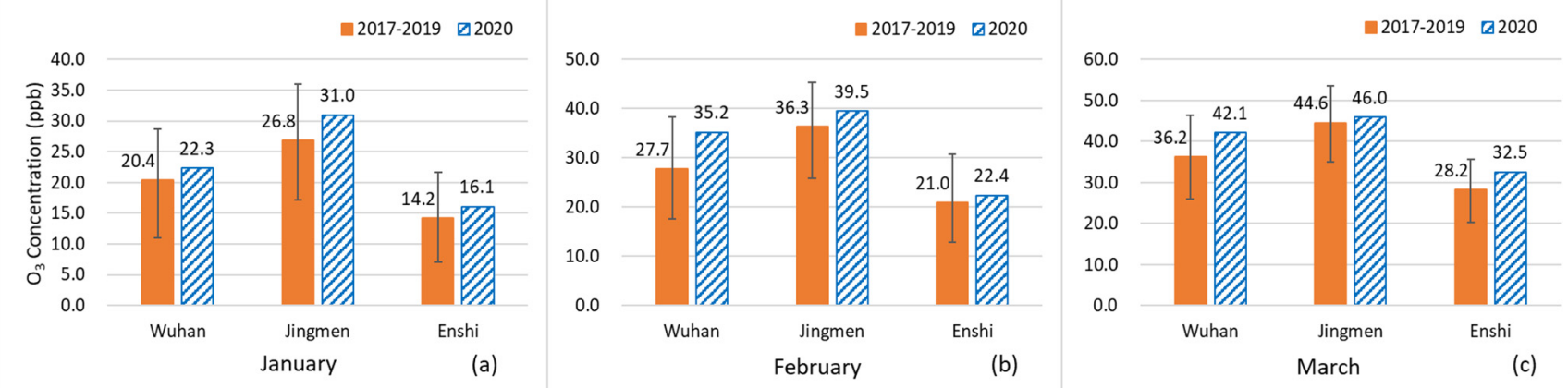

Fig. 2(F). The average concentrations of $\mathrm{O}_{3}$ in January, February and March 2017-2019 and those of 2020, respectively. 
15.4\% compared with that of during March 2017-2019. Based on the data from the three cities, during February 2020 , the average $\mathrm{O}_{3}$ rose by $11.6 \%$ compared with that in February 2017-2019.

It can be seen that from January to March 2020, the average concentration of $\mathrm{O}_{3}$ was significantly higher than the average concentration in the same period in the previous three years (2017-2019), which may have been caused by a lower level of $\mathrm{NO}_{\mathrm{x}}$ in 2020. According to previous studies, the level of $\mathrm{O}_{3}$ is closely related to $\mathrm{NO}_{2}$ and VOCs. When the $\mathrm{NO}_{\mathrm{x}}$ concentration is low, $\mathrm{NO}_{\mathrm{x}}$ promotes the formation of $\mathrm{O}_{3}$, and the concentration of VOCs has little effect on $\mathrm{O}_{3}$. When the VOC concentration is low, $\mathrm{NO}_{\mathrm{x}}$ concentration is negatively correlated with $\mathrm{O}_{3}$ production (Chameides et al., 1992). It can be seen that from January to March 2020, the $\mathrm{O}_{3}$ concentration and the $\mathrm{NO}_{2}$ concentration in the three cities are inversely proportional.

Under sufficient intensity of solar radiation, $\mathrm{NO}_{2}$ acts as a precursor in photochemical reactions and is first dissociated into $\mathrm{NO}$ and $\mathrm{O}\left({ }^{3} \mathrm{P}\right)$ :

$$
\begin{aligned}
& \mathrm{NO}_{2}+\mathrm{hv}(\lambda \leq 430 \mathrm{~nm}) \rightarrow \mathrm{NO}+\mathrm{O}\left({ }^{3} \mathrm{P}\right) \\
& \mathrm{O}\left({ }^{3} \mathrm{P}\right)+\mathrm{O}_{2} \rightarrow \mathrm{O}_{3} \\
& \mathrm{NO}+\mathrm{O}_{3} \rightarrow \mathrm{NO}_{2}+\mathrm{O}_{2}
\end{aligned}
$$

It can be seen that NOx is one of the important precursors for $\mathrm{O}_{3}$ production, and $\mathrm{NO}$ is the direct cause of $\mathrm{O}_{3}$ depletion. Lower levels of $\mathrm{NO}_{2}$ in the atmosphere will cause a reduction in $\mathrm{NO}$, which reduces the possibility of $\mathrm{NO}$ reacting with $\mathrm{O}_{3}$, resulting in the accumulation of $\mathrm{O}_{3}$. In general, urban $\mathrm{NO}_{\mathrm{x}}$ and $\mathrm{O}_{3}$ have negative correlation characteristics, which is particularly obvious in colder winter. This is because in the summer, due to the intense solar radiation and the dominant photochemical reactions that occur at this time, the environment is more suitable for the accumulation of $\mathrm{O}_{3}$. In winter, the photochemical reaction during the day is relatively weak, so a higher $\mathrm{NO}_{2}$ concentration within a specific range is beneficial to the consumption of $\mathrm{O}_{3}$, but a lower $\mathrm{NO}_{2}$ concentration causes more $\mathrm{O}_{3}$ to be generated during the day that cannot be further effectively converted (Zhao et al., 2018a; Biswas et al., 2019). This is a good explanation for the significant increase in $\mathrm{O}_{3}$ concentration in the three cities in February and March when the epidemic prevention and control actions were taken.

\section{AQI Distribution}

In order to investigate the impact of the COVID-19 outbreak on the Air Quality Index (AQI) in central China, the AQI distribution for Wuhan, Jingmen, and Enshi in January, February and March 2017-2019 and those of 2020 are shown in Fig. 3.

As shown in Fig. 3, during January 2017-2019, the average AQIs in Wuhan, Jingmen, and Enshi ranged from 45-232, 53-348, and 33-298 and averaged 119.3, 150.9, and 102.3, respectively, while those during January 2020 ranged between 40-142, 38-195, and 23-94 and averaged 83.5, 116.7, and 52.5 , respectively, which were $30.1 \%, 22.7 \%$, and $48.6 \%$, lower than those in January 2017-2019, respectively. In February 2017-2019, the average AQIs in Wuhan, Jingmen, and Enshi ranged from 28-219, 52-229, and 25-152 and averaged $93.8,112.5$, and 71.5 , respectively, while those during February 2020 ranged between 20-128, 36-185, and 23-122 and averaged 57.2, 81.3, and 62.4, respectively, which were $39.0 \%, 27.8 \%$, and $12.8 \%$, lower than those during February 2017-2019, respectively. In March 2017-2019, the average AQIs in Wuhan, Jingmen, and Enshi ranged from 33-272, 40-137, and 23-94 and averaged 80.5, 78.1, and 54.4, respectively, while those during March 2020 ranged from 28-80, 37-110, and 29-125 and averaged 55.5, 70.1, and 55.8, respectively. Those in Wuhan and Jingmen were $31.1 \%$ and $10.3 \%$ lower than those of during March $2017-$ 2019, respectively, but that of Enshi increased by $2.6 \%$ compared with that during March 2017-2019.

Based on the results for the three cities under observation, in January 2017-2019, the average AQIs ranged from 33348 and averaged 124.2, while those during January 2020 ranged between 23-195 and averaged 84 .2, which was $32.2 \%$ lower than that in January 2017-2019. In February 20172019, the average AQIs ranged from 25-229 and averaged 92.6, while those during February 2020 ranged from 20-185 and averaged 66.9 , which was $27.7 \%$ lower than that in February 2017-2019. However, in March 2017-2019, the average AQIs in the three cities ranged between 23 and 272 and averaged 71.0, while those during March 2020 ranged between 28 and 125 and averaged 60.4, which was $14.9 \%$ lower than that in March 2017-2019.

It can be seen that the air quality during January-March 2020 was significantly improved compared with the same period in 2017-2019. The improvement in air quality in January 2020 can be attributed to the reduction in industrial production and construction activities during the Lunar New Year holidays. The reduction in February and March 2020 can be attributed to the strict implementation of epidemic prevention and control actions, which has resulted in a substantial reduction in transportation and industrial emissions. In March, as the atmospheric temperature increased, the vertical dilution and dispersion of air pollutants were accelerated, and the air quality significantly improved, so the impact of epidemic prevention and control actions on air quality weakened.

\section{Distribution of Six AQI Classes}

This study also made a statistical analysis for the distribution of six AQI classes in the three cities in January, February, and March 2017-2019 and those in 2020, respectively.

It can be seen from Fig. 4(A)(a), in Wuhan, in January 2017-2019, the proportions of classes I, II, III, IV, V, and VI were $3.2 \%, 37.6 \%, 36.6 \%, 16.1 \%, 6.5 \%$, and $0 \%$, respectively. While during January 2020, the proportions of AQI classes I, II, III, IV, V, and VI were $16.1 \%, 51.6 \%$, $32.3 \%, 0 \%, 0 \%$, and $0 \%$, respectively. It can be seen that during January 2020, the combined proportions of Class I and Class II increased from $40.8 \%$ to $67.7 \%$, while the combined proportions of classes IV, V, and VI decreased from $22.6 \%$ to zero, which indicates that the air quality had greatly improved.

In Jingmen (Fig. 4(A)(a)), in January 2017-2019, the proportions of AQI classes I, II, III, IV, V, and VI were $0 \%$, 


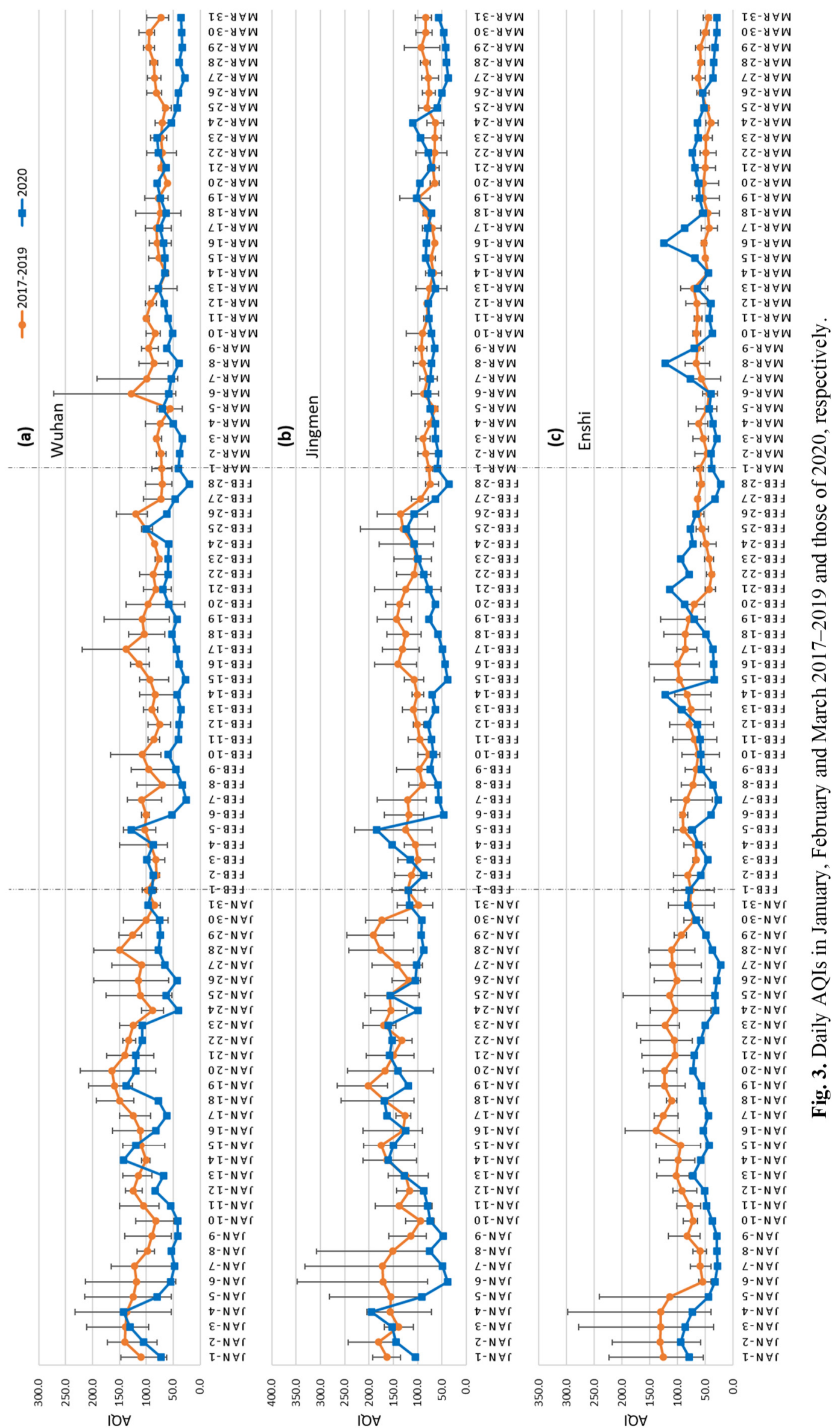



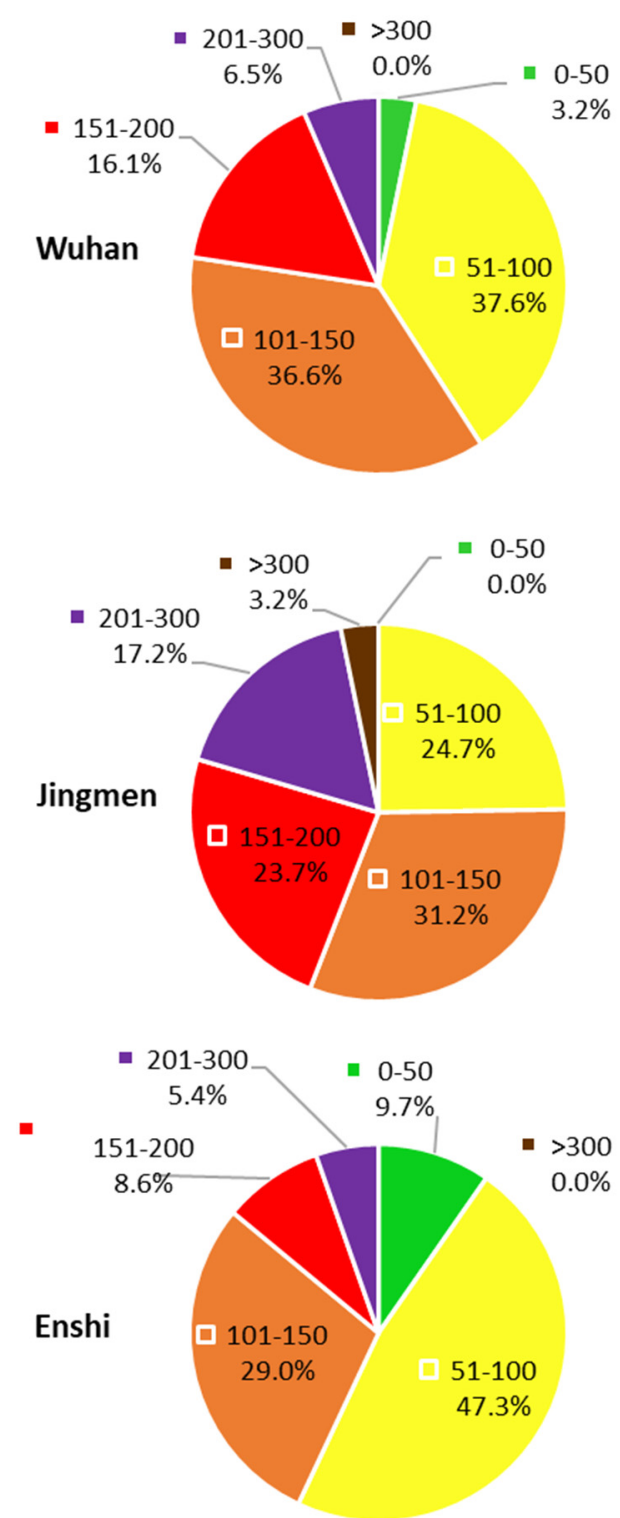

January 2017-2019

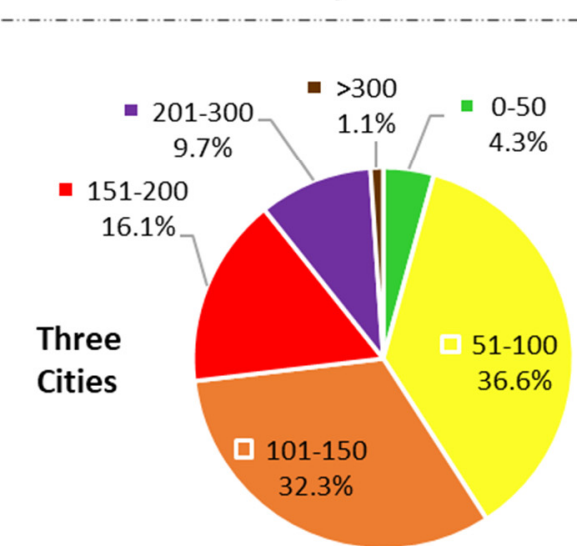

January 2017-2019
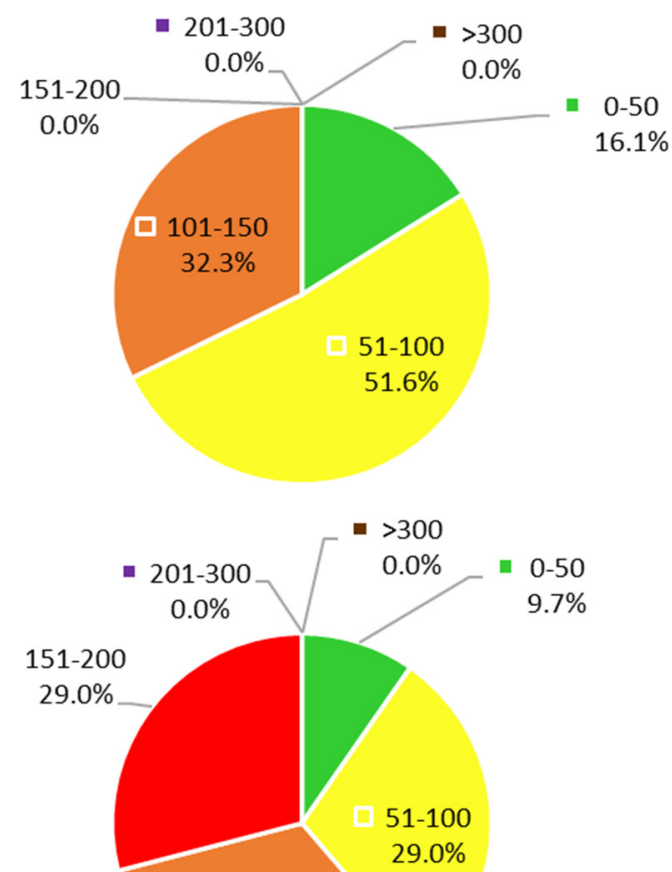

口 101-150 $32.3 \%$

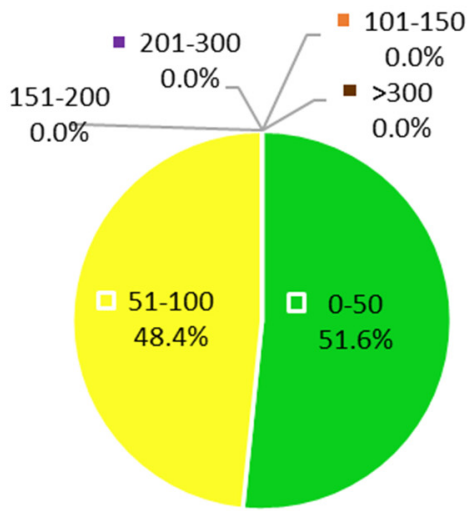

January 2020

(a)

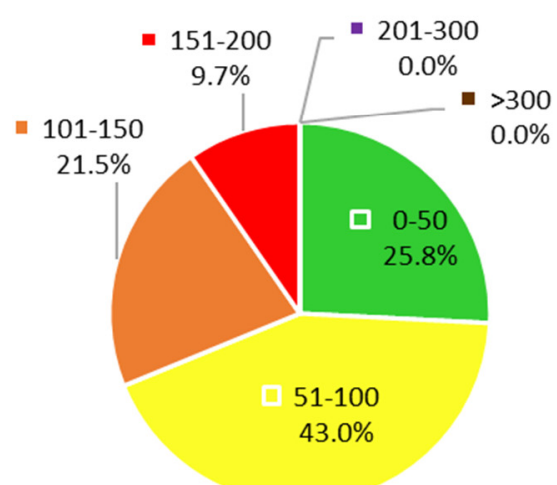

January 2020 (b)

Fig. 4(A). The distribution of six AQI classes (a) for Wuhan, Jingmen, and Enshi in January 2017-2019 and January 2020, respectively and (b) for the three cities under observation. 
$24.7 \%, 31.2 \%, 23.7 \%, 17.2 \%$, and $3.2 \%$, respectively. However, in January of 2020, those of the same AQI classes were $9.7 \%, 29.0 \%, 32.3 \%, 29.0 \%, 0 \%$, and $0 \%$, respectively. The combined proportions of classes I and II increased from $24.7 \%$ to $38.7 \%$, and the combined proportion of classes IV, $\mathrm{V}$, and VI decreased from $44.1 \%$ to $29.0 \%$.

For Enshi (Fig. 4(A)(a)), which had the greatest improvement in air quality, in January 2017-2019, the proportions of classes I, II, III, IV, V, and VI were $9.7 \%$, $47.3 \%, 29.0 \%, 8.6 \%, 5.4 \%$, and $0 \%$, respectively. In January 2020 , the same AQI class proportions were 51.6\%, 48.4\%, $0 \%, 0 \%, 0 \%$, and $0 \%$. The combined proportion of Class I and Class II increased from $57.0 \%$ to $100 \%$, respectively, while the combined proportions of classes III, VI, V, and VI decreased from $43.0 \%$ to zero. It can be seen that the air quality of the three cities in January 2020 improved very significantly compared with the same period in the previous three years.

Fig.4 (A)(b) shows the distribution of AQI classes for the three-city combination in January 2017-2019 and in January 2020, respectively. It can be seen that from 2017 to 2019, the AQI class distribution for classes I, II, III, IV, V, and VI in the three cities was $4.3 \%, 36.6 \%, 32.3 \%, 16.1 \%, 9.7 \%$, and $1.1 \%$, respectively, but in January 2020 , it was $25.8 \%$, $43.0 \%, 21.5 \%, 9.7 \%, 0 \%$, and $0 \%$, respectively. The combined proportion of classes I and II increased from $40.9 \%$ to $68.8 \%$, while that of classes VI, V, and VI decreased from $26.9 \%$ to $9.7 \%$, respectively. At the same time, classes V and VI did not appear in the three cities. Based on the data from the three cities, it can be seen that the air quality in Hubei Province in January 2020 improved from the same period in the previous three years. This may have been due to the production stagnation caused by the Chinese New Year holiday in late January and the closure of factories caused by the COVID-19 epidemic prevention and control actions.

As shown in Fig. 4(B)(a), in Wuhan, in February 20172019 , the proportions of classes I, II, III, IV, V, and VI were $6.1 \%, 56.1 \%, 32.9 \%, 3.7 \%, 1.2 \%$, and $0 \%$, respectively. In February 2020 when comprehensive epidemic prevention and control actions were taken, the proportions of classes I, II, III, IV, V, and VI were $46.4 \%, 50.0 \%, 3.6 \%, 0 \%, 0 \%$, and $0 \%$, respectively. This indicated that during the epidemic control period, the combined proportion of Class I and Class II increased from $62.2 \%$ to $96.4 \%$, while the combined proportion of classes IV, V, and VI decreased from $4.9 \%$ to zero, which indicates that the air quality improved significantly.

In Jingmen (Fig. 4(B)(a)), in February 2017-2019, the AQI proportions of classes I, II, III, IV, V, and VI were $0 \%$, $45.1 \%, 39.0 \%, 13.4 \%, 2.4 \%$, and $0 \%$, respectively. However, in February of 2020, those of AQI proportions were $17.9 \%$, $57.1 \%, 17.9 \%, 7.1 \%, 0 \%$, and $0 \%$, respectively. The combined proportions of classes I and II increased from $45.1 \%$ to $75.0 \%$, while the combined proportion of classes IV, V, and VI decreased from $15.8 \%$ to $7.1 \%$, which indicates that there was a significant improvement in air quality.

For Enshi (Fig. 4(B)(a)), in February 2017-2019, the AQI proportions of classes I, II, III, IV, V, and VI were $25.0 \%$, $57.1 \%, 16.7 \%, 1.2 \%, 0 \%$, and $0 \%$, respectively. In February 2020 , the AQI proportions were $35.7 \%, 51.1 \%, 7.1 \%, 0 \%$,
$0 \%$, and $0 \%$. This was similar to both Wuhan and Jingzhou. However, in Enshi, the combined proportion of classes I and II increased from $82.1 \%$ to $86.8 \%$, while the combined proportion of classes IV, V, and VI decreased from $1.2 \%$ to zero. Even though the improvement in air quality was not a big step, it is very clear that the epidemic prevention and control action had a good effect on air quality.

Fig. 4(B)(b) shows the distribution of AQIs for three-city combination in February 2017-2019 and in February 2020, respectively. It can be seen that from 2017 to 2019, the AQI distribution of classes I, II, III, IV, V, and VI in the three cities was $10.5 \%, 52.8 \%, 29.4 \%, 6.0 \%, 1.2 \%$, and $0 \%$, respectively, but in February 2020, the distribution was $33.3 \%, 54.8 \%, 9.5 \%, 2.4 \%, 0 \%$, and $0 \%$, respectively. The combined proportion of classes I and II increased from $63.3 \%$ to $88.1 \%$, while the combined proportion of classes IV, V, and VI decreased from $7.2 \%$ to $2.4 \%$. According to the data for the three cities, it is clear that in February 2020, the air quality of the three cities improved significantly compared with that in February 2017-2019 (non-epidemic period). This is because in February 2020, Hubei Province implemented strict epidemic prevention and control actions including quarantines, industrial plant closures, and traffic restrictions that greatly reduced air pollutant emissions.

It can be seen in Fig. 4(C)(a), that in Wuhan, in March 2017-2019, the AQI proportions of classes I, II, III, IV, V, and VI were $8.6 \%, 77.4 \%, 11.8 \%, 1.1 \%, 1.1 \%$, and $0 \%$, respectively. During March 2020 when comprehensive epidemic prevention and control action were taken, the AQI proportions of classes I, II, III, IV, V, and VI were $38.7 \%$, $61.3 \%, 0 \%, 0 \%, 0 \%$, and $0 \%$, respectively. This indicated that during the epidemic control period, the combined proportion of Class I and Class II increased from $86.0 \%$ to $100 \%$, which revealed that the air quality had greatly improved.

In Jingmen, in March 2017-2019, the AQI proportions of classes I, II, III, IV, V and VI were 5.4\%, 82.8\%, 11.8\%, 0\%, $0 \%$, and $0 \%$, respectively. However, in March of 2020, they were $16.1 \%, 77.4 \%, 6.5 \%, 0 \%, 0 \%$, and $0 \%$. The combined AQI proportions of classes I and II increased from $88.2 \%$ to $93.5 \%$, while the combined proportion of classes IV, V, and VI was zero.

For Enshi, in March 2017-2019, the AQI proportions of classes I, II, III, IV, V, and VI were 40.9\%, 59.1\%, 0\%, 0\%, $0 \%$, and $0 \%$, respectively. In March 2020, the AQI proportions were $48.4 \%, 45.2 \%, 6.5 \%, 0 \%, 0 \%$, and $0 \%$. This indicated that Enshi had good air quality in March 2017-2020. The forest coverage in Enshi accounts for about $70 \%$ of the area, so after the temperature rose in March, the vertical convention and dispersion of air pollutants was further increased, and the air quality was improved, so the control actions of the epidemic did not display a significant impact.

Fig. 4(C)(b) shows the distribution of AQI Class for the three-city combination in March 2017-2019 and in March 2020, respectively. It can be seen that from 2017 to 2019 , the AQI distribution of classes I, II, III, IV, V, and VI in the three cities was $18.3 \%, 73.1 \%, 7.9 \%, 0.4 \%, 0.4 \%$, and $0 \%$, respectively, but in March 2020, it was 34.4\%, 61.3\%, 4.3\%, $0 \%, 0 \%$, and $0 \%$, respectively. The combined proportions of classes I and II increased from $91.4 \%$ to $95.7 \%$, while the 


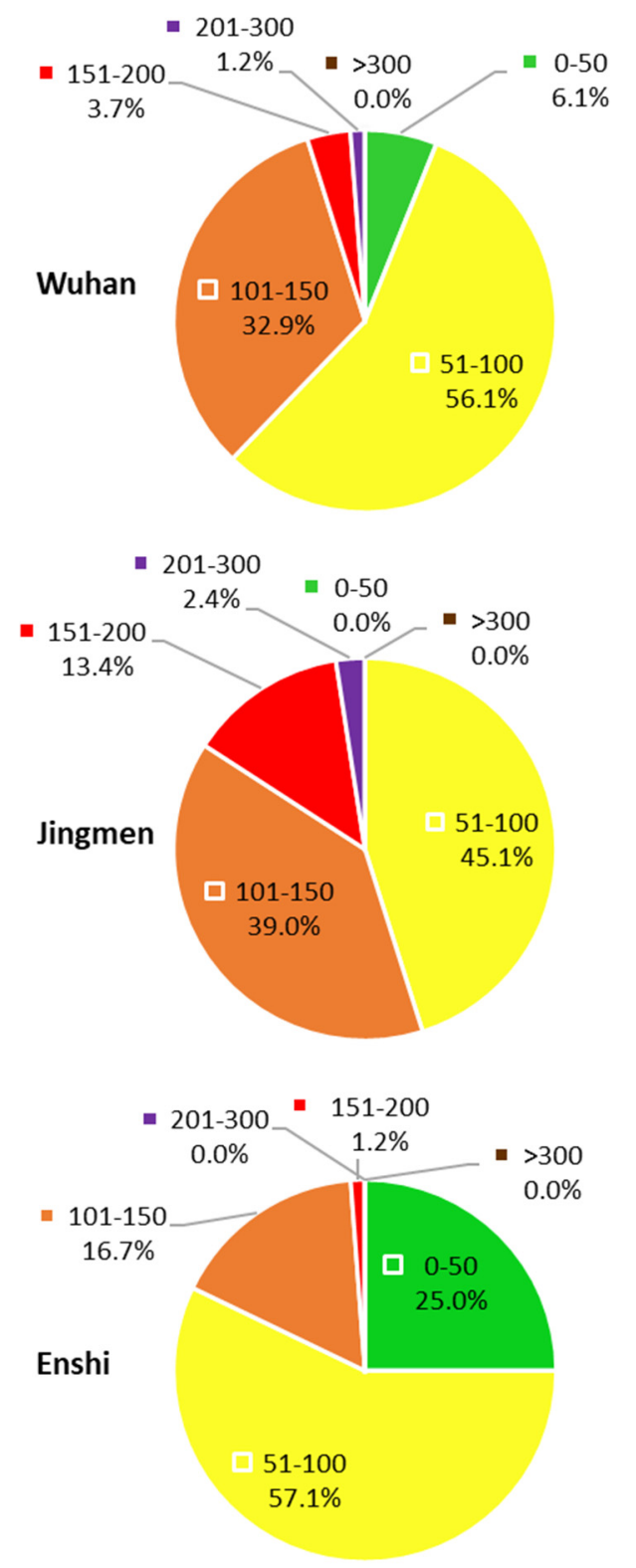

February 2017-2019

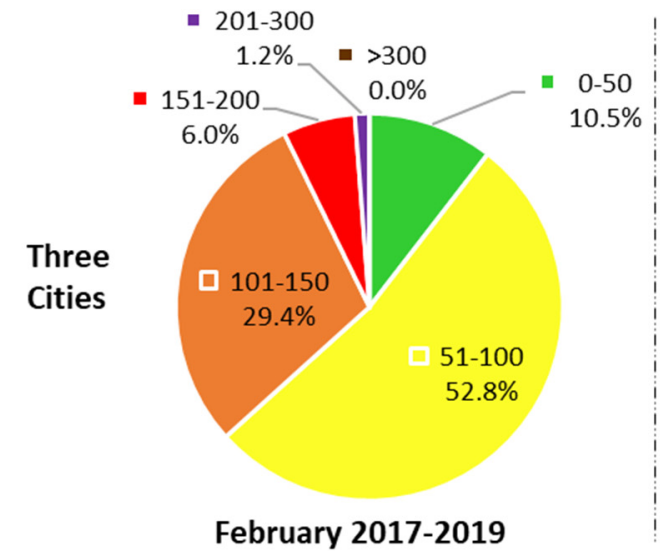

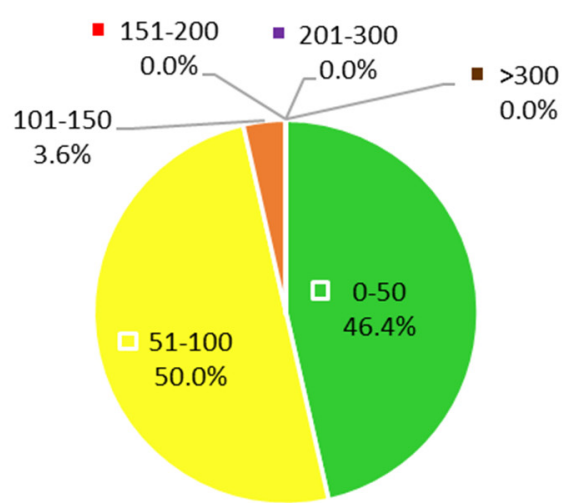
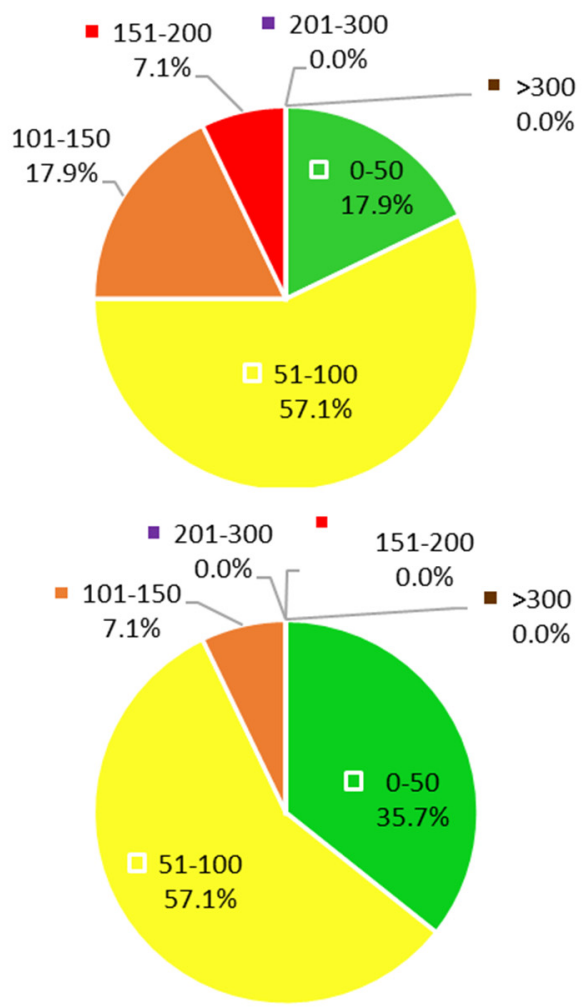

February 2020

(a)

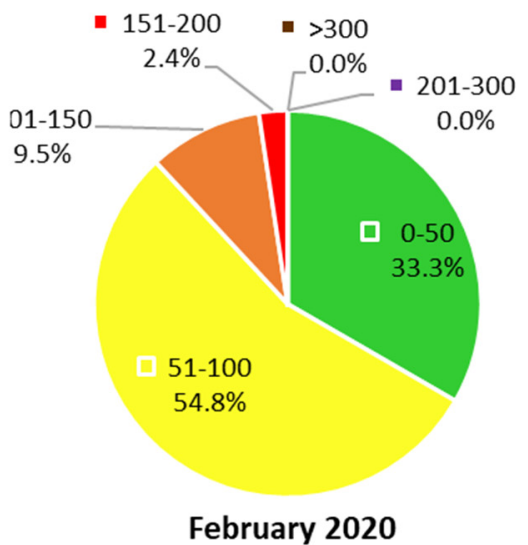

(b)

Fig. 4(B). The distribution of six AQI classes (a) for Wuhan, Jingmen, and Enshi in February 2017-2019 and February 2020, respectively and (b) for the three cities under observation. 

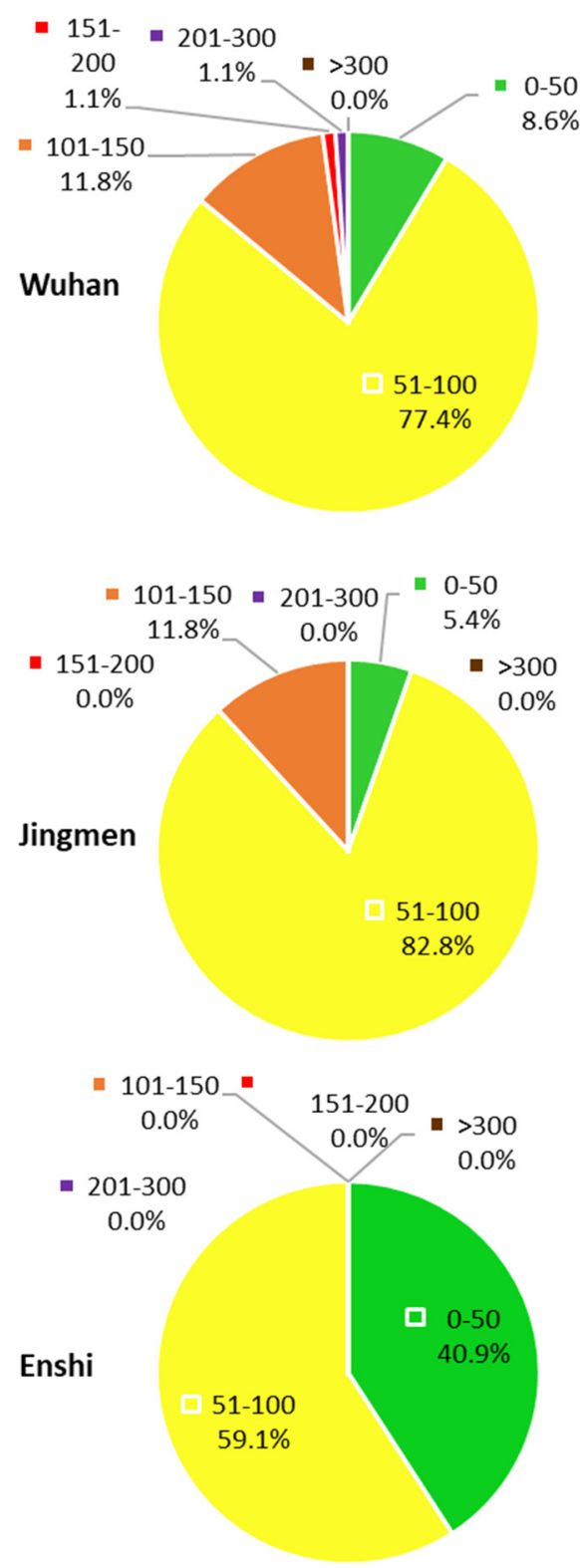

March 2017-2019

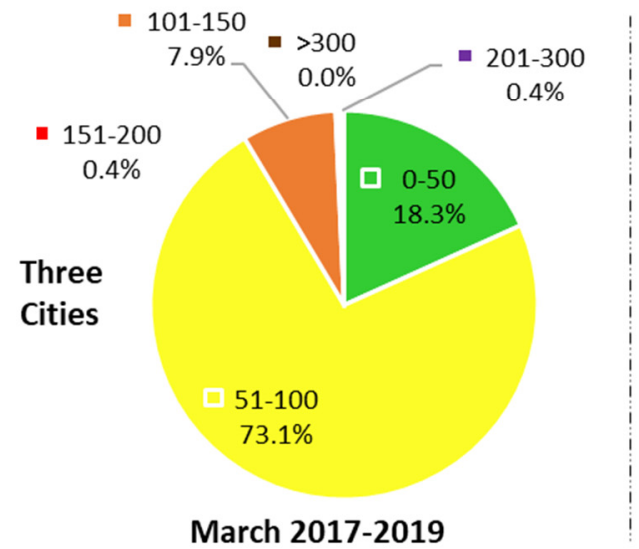

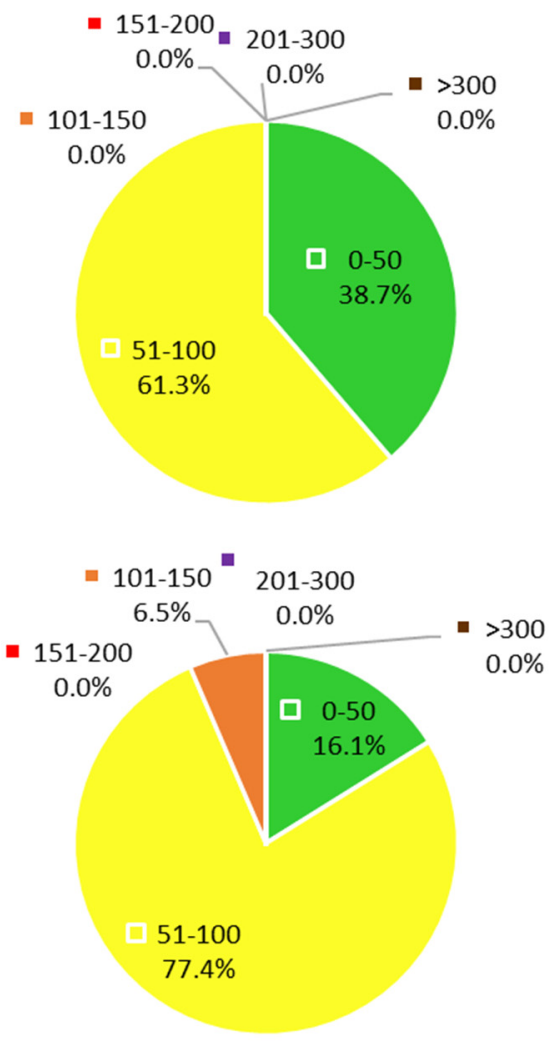

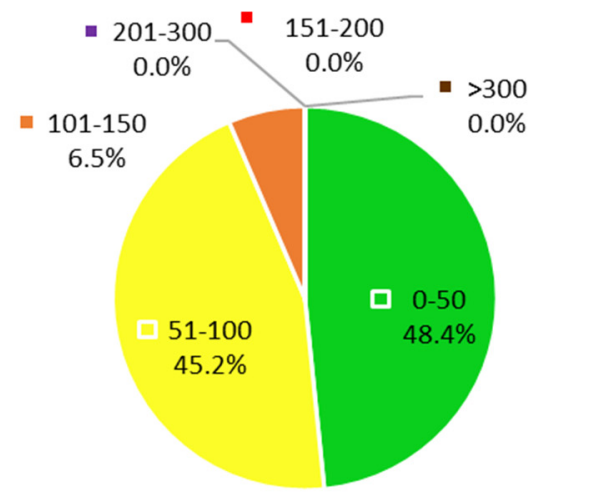

March 2020

(a)

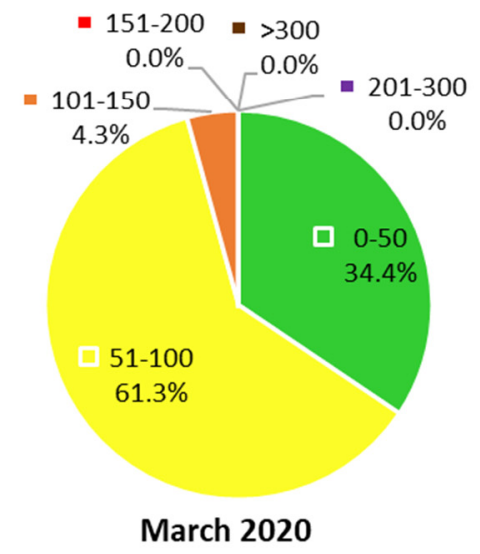

(b)

Fig. 4(C). The distribution of six AQI classes (a) for Wuhan, Jingmen, and Enshi in March 2017-2019 and March 2020, respectively and (b) for the three cities under observation. 
combined proportion of classes IV, V, and VI decreased from $0.8 \%$ to zero. Due to the strict epidemic prevention and control actions, the air quality in Hubei Province in March 2020 improved.

\section{Indicatory Air Pollutants}

The indicatory air pollutants for the different AQI classes from January to March 2017-2019 and that of 2020, respectively are shown in Table 1.

Combined with the data for the three cities, in January 2017-2019, the indicatory air pollutants for the AQIs were predominant in the following order: $\mathrm{PM}_{2.5}(92.0 \%), \mathrm{PM}_{10}$ (4.3\%), and $\mathrm{NO}_{2}(3.6 \%)$, and those of each AQI were Class I: $\mathrm{PM}_{2.5}(3.2 \%)$ (followed by $\mathrm{NO}_{2}(0.7 \%)$ and $\mathrm{PM}_{10}(0.4 \%)$ ), Class II: $\mathrm{PM}_{2.5}$ (30.1\%) (followed by $\mathrm{PM}_{10}(2.9 \%)$ and $\mathrm{NO}_{2}$ $(2.5 \%)$ ), Class III: $\mathrm{PM}_{2.5}(32.3 \%)$, Class IV: $\mathrm{PM}_{2.5}(15.7 \%)$ (followed by $\mathrm{NO}_{2}(0.4 \%)$ ), Class V: $\mathrm{PM}_{2.5}(9.7 \%)$, and Class VI: $\mathrm{PM}_{2.5}(1.1 \%)$, respectively. In January 2020 , the order was $\mathrm{PM}_{2.5}(87.0 \%), \mathrm{NO}_{2}(6.5 \%), \mathrm{O}_{3}(3.2 \%)$, and $\mathrm{PM}_{10}$ (3.2\%), and the indicatory air pollutants for each $\mathrm{AQI}$ were Class I: $\mathrm{PM}_{2.5}\left(15.1 \%\right.$ ) (followed by $\mathrm{NO}_{2}(4.3 \%), \mathrm{PM}_{10}(3.2 \%)$, and $\mathrm{O}_{3}(3.2 \%)$ ), Class II: $\mathrm{PM}_{2.5}\left(40.8 \%\right.$ ) (followed by $\mathrm{NO}_{2}$ (2.2\%)), Class III: $\mathrm{PM}_{2.5}(21.5 \%)$, and Class IV: $\mathrm{PM}_{2.5}(9.7 \%)$, respectively, while both Class V and Class VI were not present. It can be seen that in January 2020, the proportion of days with $\mathrm{NO}_{2}$ and $\mathrm{O}_{3}$ as indicatory air pollutants was slightly increased from $3.6 \%$ to $9.7 \%$, while the proportion of days with $\mathrm{PM}_{2.5}$ and $\mathrm{PM}_{10}$ as indicatory air pollutants decreased from $96.3 \%$ to $90.2 \%$ compared with that in January 2017-2019.

The combined data for the three cities in February 20172019 show that the indicatory air pollutants for the AQIs were in the following order: $\mathrm{PM}_{2.5}(74.8 \%), \mathrm{PM}_{10}(16.5 \%)$, $\mathrm{NO}_{2}(7.3 \%), \mathrm{O}_{3}(1.2 \%)$, and $\mathrm{CO}(0.4 \%)$, and those of each AQI were Class I: $\mathrm{PM}_{2.5}\left(4.8 \%\right.$ ) (followed by $\mathrm{PM}_{10}(4.4 \%)$, $\mathrm{O}_{3}(0.8 \%)$, and $\mathrm{CO}(0.4 \%)$ ), Class II: $\mathrm{PM}_{2.5}(36.4 \%)$ (followed by $\mathrm{PM}_{10}(10.9 \%), \mathrm{NO}_{2}(5.2 \%)$, and $\mathrm{O}_{3}(0.4 \%)$ ), Class III: $\mathrm{PM}_{2.5}$ (26.2\%) (followed by $\mathrm{NO}_{2}(2.0 \%)$ and $\mathrm{PM}_{10}(1.2 \%)$ ), Class IV: $\mathrm{PM}_{2.5}(6.1 \%)$, and Class V: $\mathrm{PM}_{2.5}(1.2 \%)$, respectively, and Class VI did not occur. In February 2020, during the epidemic prevention and control period, the order was $\mathrm{PM}_{2.5}$ (80.6\%), $\mathrm{O}_{3}(17.2 \%), \mathrm{PM}_{10}(1.1 \%)$, and $\mathrm{CO}(1.1 \%)$, and the indicatory air pollutants for each AQI were Class I: $\mathrm{PM}_{2.5}$ (18.4\%) (followed by $\mathrm{O}_{3}(14.9 \%)$ and $\mathrm{CO}(1.1 \%)$ ), Class II: $\mathrm{PM}_{2.5}(50.7 \%)$ (followed by $\mathrm{O}_{3}(2.3 \%)$ and $\mathrm{PM}_{10}(1.1 \%)$ ), Class III: $\mathrm{PM}_{2.5}(9.2 \%)$, and Class IV: $\mathrm{PM}_{2.5}(2.3 \%)$, respectively, while classes V and VI did not occur. It can be seen that in February 2020, the proportion of days in which $\mathrm{O}_{3}$ was as an indicatory air pollutant in classes I and II increased significantly (from 1.2\% to 17.2\%). In February 2020 , the proportion of $\mathrm{PM}_{10}$ and $\mathrm{NO}_{2}$ as indicator air pollutants decreased (from $16.5 \%$ to $1.1 \%$, and from $7.3 \%$ to $0 \%$, respectively) compared with that in February 2017-2019. This shows that during the epidemic control period, restrictions on transportation and industrial production caused significant reductions in air pollutant emissions.

The combined results for the three cities in March 2017 2019 show that the indicatory air pollutants for the AQIs were in the following order $\mathrm{PM}_{2.5}$ (45.4\%), $\mathrm{PM}_{10}$ (33.0\%),

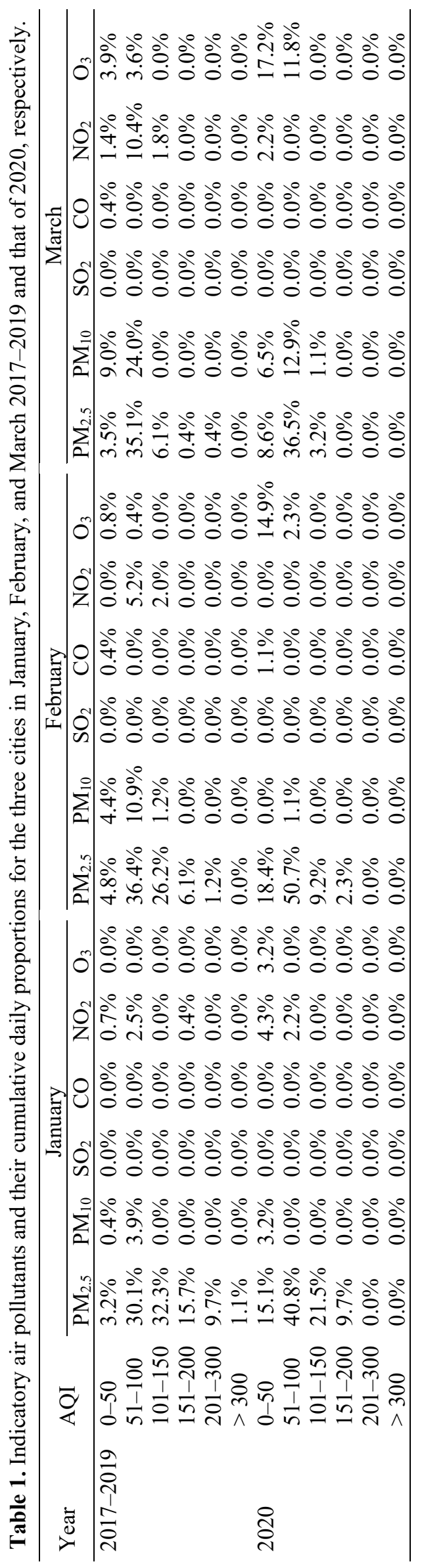


$\mathrm{NO}_{2}(13.6 \%), \mathrm{O}_{3}(7.5 \%)$, and $\mathrm{CO}(0.4 \%)$, and those of each AQI were Class I: $\mathrm{PM}_{10}(9.0 \%)$ (followed by $\mathrm{O}_{3}(3.9 \%)$, $\mathrm{PM}_{2.5}(3.5 \%), \mathrm{NO}_{2}(1.4 \%)$, and $\left.\mathrm{CO}(0.4 \%)\right)$, Class II: $\mathrm{PM}_{2.5}$ $(35.1 \%)$ (followed by $\mathrm{PM}_{10}(24.0 \%), \mathrm{NO}_{2}(10.4 \%)$, and $\mathrm{O}_{3}$ (3.6\%)), Class III: $\mathrm{PM}_{2.5}(6.1 \%)$ (followed by $\mathrm{NO}_{2}(1.8 \%)$ ), and Class IV: $\mathrm{PM}_{2.5}(0.4 \%)$, respectively, Class VI did not occur. In March 2020, they were in the following order: $\mathrm{PM}_{2.5}$ (48.3\%), $\mathrm{O}_{3}(29.0 \%), \mathrm{PM}_{10}(20.4 \%)$, and $\mathrm{NO}_{2}(2.2 \%)$, and the order of the indicatory air pollutants for each AQI were Class I: $\mathrm{O}_{3}(17.2 \%)$ (followed by $\mathrm{PM}_{2.5}(8.6 \%), \mathrm{PM}_{10}$ $(6.5 \%)$, and $\mathrm{NO}_{2}(2.2 \%)$ ), Class II: $\mathrm{PM}_{2.5}(36.5 \%)$ (followed by $\mathrm{PM}_{10}(12.9 \%)$, and $\left.\mathrm{O}_{3}(11.8 \%)\right)$, and Class III: $\mathrm{PM}_{2.5}(3.2 \%)$ (followed by $\mathrm{PM}_{10}(1.1 \%)$ ), respectively, while classes IV, $\mathrm{V}$, and VI did not occur. Consistent with the trend in February, in March 2020, the proportion of days with $\mathrm{O}_{3}$ as an indicatory air pollutant increased significantly (from $7.5 \%$ to $29.0 \%$ ), while the proportion of $\mathrm{PM}_{10}$ and $\mathrm{NO}_{2}$ as indicatory air pollutants decreased (from $33.0 \%$ to $20.4 \%$ and from $13.6 \%$ to $2.2 \%$, respectively).

To summarize, in January to March 2017-2019 in the three cities, the indicatory air pollutants for the AQIs occurred in the following order: $\mathrm{PM}_{2.5}(70.7 \%), \mathrm{PM}_{10}(17.9 \%), \mathrm{NO}_{2}$ $(8.2 \%), \mathrm{O}_{3}(2.9 \%)$, and $\mathrm{CO}(0.3 \%)$, while those in the same period in 2020 were in the following order: $\mathrm{PM}_{2.5}(72.0 \%)$, $\mathrm{O}_{3}(16.5 \%), \mathrm{PM}_{10}(8.3 \%), \mathrm{NO}_{2}(2.9 \%)$, and $\mathrm{CO}(0.4 \%)$. This indicated that from January-March 2020, the proportion of days with $\mathrm{O}_{3}$ as an indicatory air pollutant increased significantly (from $2.9 \%$ to $16.5 \%$ ), while the proportion of $\mathrm{PM}_{10}$ and $\mathrm{NO}_{2}$ as indicatory air pollutants decreased (from $17.9 \%$ to $8.3 \%$ and from $8.2 \%$ to $2.9 \%$, respectively) significantly. It can be seen that from January to March 2020, $\mathrm{PM}_{2.5}$ was still a major indicatory air pollutant. However, due to strict epidemic prevention and control actions, vehicle exhaust and industrial production emissions were significantly reduced, which caused the concentration of $\mathrm{NO}_{2}$ and $\mathrm{PM}_{10}$ to be decreased. The reason for the obvious increase in the proportion of days of $\mathrm{O}_{3}$ as an indicatory air pollutant may be that as the temperature increases, the photochemical reaction to generate $\mathrm{O}_{3}$ intensifies, but a lower level of $\mathrm{NO}_{2}$ cannot effectively convert $\mathrm{O}_{3}$, which leads to an increase in $\mathrm{O}_{3}$ levels.

\section{CONCLUSIONS}

1. The Lunar New Year holiday in late January 2020 and the COVID-19 epidemic prevention and control actions in February and March 2020 had a significant impact on the air quality of the three cities under observation. In January 2020, the average concentrations of atmospheric $\mathrm{PM}_{2.5}$, $\mathrm{PM}_{10}, \mathrm{SO}_{2}, \mathrm{CO}$, and $\mathrm{NO}_{2}$ in the three cities (combination of Wuhan, Jingmen, and Enshi) were $61.4 \mu \mathrm{g} \mathrm{m}^{-3}, 64.8 \mu \mathrm{g}$ $\mathrm{m}^{-3}, 2.39 \mathrm{ppb}, 0.73 \mathrm{ppm}$, and $13.8 \mathrm{ppb}$, and were $36.2 \%$, $37.6 \%, 45.0 \%, 28.8 \%$, and $35.6 \%$ lower than those of January 2017-2019, respectively. During February 2020, when the epidemic prevention and control actions were taken, the average concentrations of atmospheric $\mathrm{PM}_{2.5}$, $\mathrm{PM}_{10}, \mathrm{SO}_{2}, \mathrm{CO}$, and $\mathrm{NO}_{2}$ in three cities were $46.1 \mu \mathrm{g} \mathrm{m}^{-}$ ${ }^{3}, 50.8 \mu \mathrm{g} \mathrm{m}^{-3}, 2.56 \mathrm{ppb}, 0.60 \mathrm{ppm}$, and $6.70 \mathrm{ppb}$, and were $30.1 \%, 40.5 \%, 33.4 \%, 27.9 \%$, and $61.4 \%$ lower than those of February 2017-2019, respectively. As for March 2020, these concentrations were $38.2 \mu \mathrm{g} \mathrm{m}^{-3}, 57.2 \mu \mathrm{g} \mathrm{m}^{-3}, 2.81$ $\mathrm{ppb}, 0.59 \mathrm{ppm}$, and $8.04 \mathrm{ppb}$, and were $15.8 \%, 22.5 \%$, $29.7 \%, 20.3 \%$, and $56.6 \%$ lower than those of March 2017-2019, respectively.

2. It is worth noting that the pattern of $\mathrm{O}_{3}$ concentration was completely opposite to the pattern of the other five air pollutants $\left(\mathrm{PM}_{2.5}, \mathrm{PM}_{10}, \mathrm{SO}_{2}, \mathrm{CO}\right.$, and $\left.\mathrm{NO}_{2}\right)$. The average concentrations of atmospheric $\mathrm{O}_{3}$ in three cities in January, February and March 2017-2019 were 20.5, 28.2, and $36.3 \mathrm{ppb}$, respectively, while those in 2020 were 23.1 , 32.4 , and $38.3 \mathrm{ppb}$, respectively, which were $12.7 \%, 14.3 \%$, and $11.6 \%$ higher than those of 2017-2019, respectively. This is because a lower concentration of $\mathrm{NO}_{2}$ hindered the $\mathrm{NO}+\mathrm{O}_{3}$ reaction, so $\mathrm{O}_{3}$ was could not be effectively depleted further.

3 . Based on the results for the three cities, in January, February, and March 2017-2019, the AQIs averaged 124.2, 92.6, and 71.0 respectively, while those during 2020 averaged $84.2,66.9$, and 60.4 , respectively, and were $32.2 \%, 27.7 \%$, and $14.9 \%$ lower than that in 2017-2019. The improvement in air quality in January 2020 can be attributed to the reduction in industrial production and construction activities during the Lunar New Year holidays. The reduction in February and March 2020 can be attributed to the strict implementation of epidemic prevention and control actions, which resulted in a substantial reduction in transportation and industrial emissions.

4. Based on the combination of the three cities, the combined proportion of AQI Classes I and Class II in January, February and March 2020, increased by $27.9 \%$, 24.8\%, and $4.3 \%$, respectively, while the combined proportion of AQI classes IV, V, and VI was reduced by $17.2 \%, 4.8 \%$, and $0.8 \%$ respectively. It is clear that from JanuaryMarch 2020, the air quality of the three cities improved significantly compared with that in 2017-2019.

5. As to the indicatory air pollutants for the different AQI Classes in three cities, the results indicated that during January-March 2020, the proportion of days with $\mathrm{O}_{3}$ as an indicatory air pollutant, increased (from $2.9 \%$ to $16.5 \%$ ), while the proportions of $\mathrm{PM}_{10}$ and $\mathrm{NO}_{2}$ decreased (from $17.9 \%$ to $8.3 \%$ and from $8.2 \%$ to $2.9 \%$, respectively). During January-March $2020, \mathrm{PM}_{2.5}$ was still a major indicatory air pollutant. However, due to strict epidemic prevention and control actions, the emissions from vehicle exhaust and industrial production were significantly reduced, which caused the concentration of $\mathrm{NO}_{2}$ and $\mathrm{PM}_{10}$ to be decreased. The reason for the obvious increase in the proportion of days with $\mathrm{O}_{3}$ as an indicatory air pollutant may be that as the temperature increased, the photochemical reaction to generate $\mathrm{O}_{3}$ intensified, but a lower level of $\mathrm{NO}_{2}$ and $\mathrm{NO}$ made it impossible to effectively convert $\mathrm{O}_{3}$, which led to an increase in $\mathrm{O}_{3}$ levels.

\section{REFERENCES}

Biswas, M.S., Ghude, S.D., Gurnale, D., Prabhakaran, T. and Mahajan, A.S. (2019). Simultaneous observations of nitrogen dioxide, formaldehyde and ozone in the Indo- 
Gangetic Plain. Aerosol Air Qual. Res. 19: 1749-1764.

Burnett, R.T., Stieb, D., Brook, J.R., Cakmak, S., Dales, R., Raizenne, M., Vincent, R. and Dann, T. (2004). Associations between short-term changes in nitrogen dioxide and mortality in Canadian cities. Arch. Environ. Health 59: 228-236.

Chameides, W.L., Fehsenfeld, F., Rodgers, M.O., Cardelino, C., Martinez, J., Parrish, D., Lonneman, W., Lawson, D.R., Rasmussen, R.A., Zimmerman, P., Greenberg, J., Mlddleton, P. and Wang, T. (1992). Ozone precursor relationships in the ambient atmosphere. J. Geophys. Res. 97: 6037.

Dockery, D.W., Pope, C.A., Xu, X., Spengler, J.D., Ware, J.H., Fay, M.E., Ferris, B.G. and Speizer, F.E. (1993). An association between air pollution and mortality in six US cities. N. Engl. J. Med. 329: 1753-1759.

http://www.tianqihoubao.com/lishi/

http://www.xinhuanet.com/2020-04/12/c_1125845334.htm

Hu, J., Ying, Q., Wang, Y. and Z̄hang, H. (2015). Characterizing multi-pollutant air pollution in China: Comparison of three air quality indices. Environ. Int. 84: 17-25.

Jaeglé, L., Steinberger, L., Martin, R.V. and Chance, K. (2005). Global partitioning of $\mathrm{NO}_{\mathrm{x}}$ sources using satellite observations: Relative roles of fossil fuel combustion, biomass burning and soil emissions. Faraday Discuss. 130: 407-423.

Kato, S., Shiobara, Y., Uchiyama, K., Miura, K., Okochi, H., Kobayashi, H. and Hatakeyama, S. (2016). Atmospheric $\mathrm{CO}, \mathrm{O}_{3}$, and $\mathrm{SO}_{2}$ measurements at the summit of Mt. Fuji during the Summer of 2013. Aerosol Air Qual. Res. 16: 2368-2377.

Kong, S.F., Ji, Y.Q., Lu, B., Chen, L., Han, B., Li, Z.Y. and Bai, Z.P. (2011). Characterization of $\mathrm{PM}_{10}$ source profiles for fugitive dust in Fushun-A city famous for coal. Atmos. Environ. 45: 5351-5365.

Lee, Y.Y., Wang, L.C., Zhu, J.N., Wu, J.L. and Lee, K.L. (2018). Atmospheric $\mathrm{PM}_{2.5}$ and polychlorinated dibenzo$p$-dioxins and dibenzofurans in Taiwan. Aerosol Air Qual. Res. 18: 762-779.

Li, X., Qiao, Y. and Shi, L. (2017). The aggregate effect of air pollution regulation on $\mathrm{CO}_{2}$ mitigation in China's manufacturing industry: An econometric analysis. $J$. Cleaner Prod. 142: 976-984.

Logan, J.A., Prather, M.J., Wofsy, S.C. and Mcelroy, M.B. (1981). Tropospheric chemistry: A global perspective. $J$. Geophys. Res. 86: 7210-7254.

Ning, G., Wang, S., Ma, M., Ni, C., Shang, Z., Wang, J. and $\mathrm{Li}$, J. (2018). Characteristics of air pollution in different zones of Sichuan Basin, China. Sci. Total Environ. 612: 975-984.

Pope III, C.A., Burnett, R.T., Thun, M.J., Calle, E.E., Krewski, D., Ito, K. and Thurston, G.D. (2002). Lung cancer, cardiopulmonary mortality, and long-term exposure to fine particulate air pollution. JAMA 287: 1132.

Ryerson, T.B., Trainer, M., Holloway, J.S., Parrish, D.D., Huey, L.G., Sueper, D.T., Frost, G.J., Donnelly, S.G., Schauffler, S., Atlas, E.L., Kuster, W.C., Goldan, P.D., Hubler, G., Meagher, J.F. and Fehsenfeld, F.C. (2001). Observations of ozone formation in power plant plumes and implications for ozone control strategies. Science 292: 719-723.

Scharte, M., Bone, H.G., Van Aken, H. and Meyer, J. (2000). Increased carbon monoxide in exhaled air of critically ill patients. Biochem. Biophys. Res. Commun. 267: 423-426.

She, Q.N., Peng, X., Xu, Q., Long, L.B., Wei, N., Liu, M. and Jia, W.X. (2017). Air quality and its response to satellite-derived urban form in the Yangtze River Delta, China. Environ. Res. Sci. 75: 297-306.

Shen, F.Z., Ge, X.L., Hu, J.L., Nie, D.Y., Tian, L. and Chen, M.D. (2017). Air pollution characteristics and health risks in Henan Province, China. Environ. Res. Sci. 156: 625634.

Tao, J., Ho, K.F., Chen, L., Zhu, L., Han, J. and Xu, Z. (2009). Effect of chemical composition of $\mathrm{PM}_{2.5}$ on visibility in Guangzhou, China, 2007 Spring. Particuology 7: 68-75.

Tong, Z., Chen, Y., Malkawi, A., Liu, Z. and Freeman, R.B. (2016). Energy saving potential of natural ventilation in China: The impact of ambient air pollution. Appl. Energy 179: 660-668.

Wang, H. and Chen, H. (2016). Understanding the recent trend of haze pollution in eastern China: Roles of climate change. Atmos. Chem. Phys. 16: 4205-4211.

Wang, H., Xu, J., Zhang, M., Yang, Y., Shen, X., Wang, Y., Chen, D. and Guo, J. (2014). A study of the meteorological causes of a prolonged and severe haze episode in January 2013 over central-eastern China. Atmos. Environ. 98: 146157.

Xu, G., Jiao, L.M., Zhang, B.E., Zhao, S.L., Yuan, M., Gu, Y.Y., Liu, J.F. and Tang, X. (2017). Spatial and temporal variability of the $\mathrm{PM}_{2.5} / \mathrm{PM}_{10}$ ratio in Wuhan, central China. Aerosol Air Qual. Res. 17: 741-751.

Zhao, R., Cui, K.P., Wang, W.W., Wang, L.C. and Yan, P. (2018a). Atmospheric $\mathrm{PM}_{2.5}$ and total PCDD/Fs$\mathrm{WHO}_{2005}$-TEQ level: A case of Handan and Kaifeng cities, China. Aerosol Air Qual. Res. 18: 994-1007.

Zhao, S., Yu, Y., Yin, D., Qin, D., He, J. and Dong, L. (2018b). Spatial patterns and temporal variations of six criteria air pollutants during 2015 to 2017 in the city clusters of Sichuan Basin, China. Sci. Total Environ. 624: 540-557.

Received for review, April 16, 2020 Revised, April 22, 2020 Accepted, April 28, 2020 